\title{
Pharmacotherapy in Oral and Maxillofacial Surgery
}

\author{
Latha P. Rao
}

The human fascination-and sometimes infatuation-with chemicals that alter biological function is ancient and results from long experience with, and dependence on, plants. Many plants produce harmful compounds for defense that animals have learned to avoid and humans to exploit [1]

\subsection{Introduction}

With phenomenal increase in the knowledge about mechanism of action of chemical compounds and rapid introduction of new drugs, pharmacology — the science of drugs — has become increasingly important to all health professionals. Practice of maxillofacial surgery utilizes drugs either as primary treatment modality or as a facilitator of surgical procedures. A detailed description of the pharmacodynamics \& pharmacokinetics of these drugs is beyond the scope of this chapter. The readers are encouraged to refer to the standard textbooks of pharmacology for the same.

\subsection{Antimicrobial Agents}

Infections caused by microorganisms have threatened human life since time immemorial. Some of the organisms had the potential to spread from one infected person to another at an alarming rate causing worldwide pandemics and epidemics. With the discovery of the first antibiotic, "the magic bullet"-Penicillin, patients could effectively be cured of many life- threatening infections [2].

Antimicrobial agents are of the few classes of drugs that effectively treat the etiology of conditions and not simply alleviate the symptoms of the diseases.

L. P. Rao ( $ه)$

Department of craniomaxillofacial surgery, Aster Medcity, Kochi, Kerala, India

\subsubsection{Definition}

The term antibiotic was first used by Selman Waksman et al. to describe any substance produced by a microorganism that is antagonistic to the growth of other microorganisms in high dilution [3]. This definition excluded substances like gastric juices and hydrogen peroxide that kill bacteria but are not produced by microorganisms. It also excluded synthetic antibacterial compounds like the sulfonamides. In current usage, however, the term "antibiotic" is applied to any medication that kills bacteria or inhibits their growth, regardless of whether that medication is produced by a microorganism or not.

\subsubsection{Classification}

The antibiotics have been classified in many ways, based on their chemical nature, mechanism of action, type of organisms against which primarily active spectrum of activity, etc. (Table 10.1). The antibiotics exert their remarkably specific action on the microorganisms, sparing the host, due to their selectivity for target components, which are either absent or not very important in humans. Among these targets are bacterial and fungal cell wall synthesizing enzymes, the bacterial ribosome, the enzymes required for nucleotide synthesis and DNA replication, etc.

\subsubsection{Oral Microflora}

The infectious diseases associated with the oral and maxillofacial region have unique microbiological features because of the abundance and variety of microorganisms in this region. The normal flora of the oral cavity consists of up to $10^{11}$ bacteria per gram of tissue, with anaerobic bacteria predominating [4]. Although the subtypes and proportions of organisms differ, the general pattern of the indigenous 
Table 10.1 Different classes of antibiotics-based on their chemical structure and mechanism of actions

\begin{tabular}{|c|c|c|c|}
\hline Class of antibiotics & Common examples & Mechanism of action & $\begin{array}{l}\text { Bacteriostatic / } \\
\text { Bactericidal }\end{array}$ \\
\hline Beta lactams - most widely used & $\begin{array}{l}\text { (a) Penicillins } \\
\text { (b) Cephalosporins }\end{array}$ & $\begin{array}{l}\text { Inhibit bacterial cell wall } \\
\text { synthesis }\end{array}$ & Bactericidal \\
\hline Sulfonamides - first commercial antibiotics & $\begin{array}{l}\text { (a) Sulfanilamide } \\
\text { (b) Sulfadiazine } \\
\text { (c) Sulfizoxazole }\end{array}$ & $\begin{array}{l}\text { Prevent bacterial growth and } \\
\text { multiplication }\end{array}$ & Bacteriostatic \\
\hline Aminoglycosides & $\begin{array}{l}\text { (a) Streptomycin } \\
\text { (b) Neomycin } \\
\text { (c) Kanamycin } \\
\text { (d) Paramomycin }\end{array}$ & Inhibit bacterial protein synthesis & Bactericidal \\
\hline $\begin{array}{l}\text { Tetracyclines-more chances of resistance } \\
\text { formation }\end{array}$ & $\begin{array}{l}\text { (a) Tetracyclines } \\
\text { (b) Doxycycline } \\
\text { (c) Oxytretracycline }\end{array}$ & Inhibit bacterial protein synthesis & Bacteriostatic \\
\hline $\begin{array}{l}\text { Chloramphenicol_-first line of drug only in } \\
\text { conjunctivitis }\end{array}$ & & Inhibit bacterial protein synthesis & Bacteriostatic \\
\hline Macrolides_-second most prescribed & $\begin{array}{l}\text { (a) Erythromycin } \\
\text { (b) Clarithromycin } \\
\text { (c) Azithromycin }\end{array}$ & Inhibit bacterial protein synthesis & Bacteriostatic \\
\hline Glycopeptides-last-resort drugs & $\begin{array}{l}\text { (a) Vancomycin } \\
\text { (b) Teicoplanin }\end{array}$ & $\begin{array}{l}\text { Inhibit bacterial cell wall } \\
\text { synthesis }\end{array}$ & Bactericidal \\
\hline Ansamycins - have antiviral activity also & $\begin{array}{l}\text { (a) Geldanamycin } \\
\text { (b) Rifamycin } \\
\text { (c) Naphthomycin }\end{array}$ & Inhibit bacterial RNA synthesis & Bactericidal \\
\hline $\begin{array}{l}\text { Quinolones-rapid development of } \\
\text { resistance }\end{array}$ & $\begin{array}{l}\text { (a) Ciprofloxacin } \\
\text { (b) Levofloxacin } \\
\text { (c) Trovafloxacin }\end{array}$ & $\begin{array}{l}\text { Inhibit bacterial cell wall } \\
\text { synthesis }\end{array}$ & Bactericidal \\
\hline $\begin{array}{l}\text { Streptogramins - two groups of antibiotics } \\
\text { that act synergistically }\end{array}$ & $\begin{array}{l}\text { (a) Pristinamycin I A } \\
\text { (b) Pristinamycin II A }\end{array}$ & Inhibit bacterial protein synthesis & Bactericidal \\
\hline Oxazolidinones - potent last-resort drugs & $\begin{array}{l}\text { (a) Linezolid } \\
\text { (b) Posizolid } \\
\text { (c) Tedizolid } \\
\text { (d) Cycloserine }\end{array}$ & Inhibit bacterial protein synthesis & Bacteriostatic \\
\hline Leptopeptides - instances of resistance rare & $\begin{array}{l}\text { (a) Daptomycin } \\
\text { (b) Surfactin }\end{array}$ & $\begin{array}{l}\text { Disrupt multiple cell-membrane } \\
\text { functions }\end{array}$ & Bactericidal \\
\hline
\end{tabular}

microflora is similar in healthy individuals. However, systemic diseases and concurrent use of medications result in the presence of unusual organisms as part of the normal flora and an increase in diseases caused by normal organisms that usually are considered to have low pathogenicity. Usually, the microorganisms are held in check by the body's defense mechanisms. When these mechanisms are impaired, infection may result from an otherwise minor bacterial exposure.

The pathobiology of mixed odontogenic infection is relatively clear. The early cellulitis is the result of streptococci, the moderate-to-severe infection is caused by a combination of aerobic and anaerobic bacteria, and the well- circumscribed chronic abscess is caused primarily by anaerobic bacilli alone [5]. A complex mix of strict anaerobes and facultative anaerobes account for most of the odontogenic infections. Empirical antibiotic choices can be made in this situation where the microbiological pattern is well established (Table 10.2).

\subsubsection{Guidelines to the Therapeutic Use of Antibiotics}

Understanding that infections are ultimately dealt by the host's immune systems, and antibiotics play only an adjunctive role, is critical. Antibiotic therapy should be reserved for those with clearly established infection. Surgical treatment of the infection also should be initiated as early as possible.

Antibiotics help in preventing infections after a contamination has happened or they can abort a developing infection, if administered early. Antibiotics should not be used as a substitute for the needed surgical treatment.

In most clinical situations, it is easy to determine whether a patient has an infection-local and systemic findings would point to the diagnosis. Diagnostic difficulty arises when a patient who has had a maxillofacial procedure performed, during the second or third day after surgery, develops swelling and pain. Similarly, elevated temperature and white blood cell count also may be found. Surgical insult and 
Table 10.2 Efficacy of commonly used antibiotics against head and neck pathogens and dosage

\begin{tabular}{|c|c|c|c|c|}
\hline Antibiotics & Aerobes & Staphylococcus & Anaerobes & Dose \\
\hline Penicillin & Excellent & No action & $\begin{array}{l}\text { Guarded against prevotella, } \\
\text { porphyromonas, fusobacterium, } \\
\text { bacteroides }\end{array}$ & $\begin{array}{l}\text { Penicillin G- } 6,00,000- \\
1,200,000 \text { u q4h im/iv } \\
\text { Penicillin V - 250- } \\
500 \text { mg q6h orally }\end{array}$ \\
\hline $\begin{array}{l}\text { Amoxycillin / } \\
\text { clavulanate }\end{array}$ & Excellent & Active & $\begin{array}{l}\text { Guarded against prevotella, } \\
\text { porphyromonas, fusobacterium, } \\
\text { bacteroides }\end{array}$ & $\begin{array}{l}375-625 \mathrm{mg} \text { q } 8 \mathrm{~h} \text { orally } \\
1.2 \mathrm{~g} \mathrm{q} 8 \mathrm{~h} \mathrm{im} / \mathrm{iv}\end{array}$ \\
\hline Cefuroxime & $\begin{array}{l}\text { Excellent with all except guarded } \\
\text { action against capnocytophaga and no } \\
\text { action against eikenella }\end{array}$ & Active & $\begin{array}{l}\text { No action against prevotella, } \\
\text { porphyromonas, fusobacterium, } \\
\text { bacteroides }\end{array}$ & $1.5 \mathrm{~g} \mathrm{q} 8 \mathrm{~h} \mathrm{im/iv}$ \\
\hline Erythromycin & $\begin{array}{l}\text { Good, guarded against } \\
\text { capnocytophaga \& eikenella }\end{array}$ & Active & $\begin{array}{l}\text { Guarded action against fusobacterium, } \\
\text { no action against prevotella, } \\
\text { porphyromonas, bacteroides }\end{array}$ & $\begin{array}{l}250-500 \mathrm{mg} \text { q6h orally } \\
1-4 \mathrm{~g} / \text { day in divided } \\
\text { doses q6h iv for severe } \\
\text { infections }\end{array}$ \\
\hline Clindamycin & Excellent & Active & Active & $\begin{array}{l}150-300 \mathrm{mg} \text { q } 8 \mathrm{~h} \text { orally } \\
1200-2400 \mathrm{mg} / \text { day in } \\
\text { divided doses q8h for } \\
\text { severe infections }\end{array}$ \\
\hline Ciprofloxacin & Good & Guarded action & Guarded action & $\begin{array}{l}500 \mathrm{mg} \mathrm{q} 12 \mathrm{~h} \text { orally } \\
400 \mathrm{mg} \mathrm{q} 12 \mathrm{~h} \text { iv }\end{array}$ \\
\hline Metronidazole & No action & No action & Active & $\begin{array}{l}400 \mathrm{mg} \text { q } 8 \mathrm{~h} \text { orally } \\
500 \mathrm{mg} \text { q } 8 \mathrm{~h} \text { iv }\end{array}$ \\
\hline
\end{tabular}

prolonged general anesthesia often result in these symptoms. Clinical judgment is important in making the diagnosis, and the clinician should weigh all information available before making the diagnosis of infection.

There are a few basic guidelines to be followed in the administration of antibiotics (Table 10.3).

\subsubsection{Consistency in Route of Administration}

In severe infection, parenteral antibiotics are needed to get adequate blood levels. But with an initial response within couple of days, one is always tempted to switch to oral administration. When this is done, the infection may recur because blood levels achieved with oral dose are suboptimal. Maintenance of peak blood levels of antibiotic, until eradication of bacteria, is important, which may take 5-6 days. After the fifth day of parenteral administration, the blood levels achievable with oral administration are usually sufficient.

\subsubsection{Cross-allerginicity between Penicillins \& Cephalosporins}

A frequently asked question about penicillin allergic patients is whether the cephalosporins can be used safely. Overall the frequency of crossallergenicity between the two groups of drugs is low (7-18\%) [10,11]. Cross-allergenicity appears to be most common among penicillin, aminopenicillins, and early-generation cephalosporins, which share similar R-1 side chains; this is thought to increase the risk of cross-reactivity. Patients with a history of anaphylaxis to penicillins should not receive first- or second-generation cephalosporins, while third- and fourth-generation cephalosporins should be administered with caution, preferably in a monitored setting.

\subsubsection{Patient Monitoring}

The patient should be monitored for the response to treatment and any deterrent should be identified and rectified. A second empirical choice should be avoided, if at all possible because the likelihood of success is substantially less. Repeat cultures may also be attempted.

In some cases, the patient may respond well to the empirical antibiotics, but the culture and sensitivity report would reveal that the organisms isolated are resistant to the antibiotics being used. The combined surgical and antibiotic treatment, along with natural host defenses, would have resulted in resolution of infection. The antibiotic may or may not have played an important role. The antibiotic that was clinically effective for the patient should be continued despite the contradictory data.

\subsection{General Considerations in the Prophylactic Use of Antibiotics}

The original guidelines for timing and use of antibiotics to prevent infection postoperatively were established by Burke and Miles et al.'s experimental observations [12, 13]. They 
Table 10.3 Guidelines for the use of antibiotics

1. Empirical therapy

2. Identification of the organisms - obtain culture \& sensitivity in

(a) Compromised host defenses

(b) Persistence of infection in spite of appropriate antibiotics \& surgical therapy.

(c) Postoperative infection

(d) Suspected cases of actinomycosis, osteomyelitis

3. Use of specific narrow-spectrum antibiotic - to prevent/ minimize bacterial resistance [6] \& superinfections [7].

4. Reserve combination therapy for:

(a) Patient with life-threatening sepsis of unknown cause

(b) Increased bactericidal effect against a specific organism is required

(c) Prevention of rapid emergence of resistant bacteria-e.g., tuberculosis

(d) Empiric treatment for certain odontogenic infections-that are rapidly progressing posteriorly around the neck space

5. Use of antibiotics with proven history of success

6. Use of the least toxic antibiotic

7. Use of a bactericidal rather than a bacteriostatic drug

8. Proper administration: Dose, time interval, route of administration, \& consistency in the route of administration

9. Cost of the antibiotics

10. Patient compliance - decreases with increasing number of pills [8]

11. Patient monitoring - initially a subjective sense of feeling better, then look for reduction in swelling, pain, \& temperature [9]

12. Causes of failure of antibiotic therapy:

(a) Inadequate surgical intervention -

(i) Failure to drain pus,

(ii) Increasing pressure inside tissue spaces,

(iii) Retained nonvital tissue or foreign body.

(b) Other sources of infection-IV catheter, Foley's catheter

(c) Reduced or compromised host defensesimmunocompromised, malnourished, dehydrated patients

(d) Mistakes in antibiotic administration

(i) Improper route of administration,

(ii) Inadequate dosage,

(iii) Patient noncompliance,

(iv) Incorrect carrying out of physician's orders.

(e) Wrong culture report or misinterpretation of the culture report

noted that antibiotics must be given within $4 \mathrm{~h}$ after injection of bacteria into a surgical site to prevent the aggressive level of infection that occurs when no antibiotics are administered.

Antibiotic prophylaxis entails administering the antibiotic appropriate for the potential microbial contamination before the surgical insult, at a high enough dosage to establish an appropriate bacteriologic titer [14].

1. Indications for antibiotic prophylaxis $[15,16]$ are given in Table 10.4 .

2. Condition \& bacterial contamination of the surgical area: Surgical wounds are generally classified into clean, clean-contaminated, contaminated, and dirty/infected [16-18] (Table 10.5).

With judicious use of antibiotics, the infection rates are known to be lesser $[16,18]$.
Table 10.4 Indications for antibiotic prophylaxis

1. Compromised host defenses

(a) Physiological—old age, obesity, malnutrition

(b) Disturbances in circulation-massive transfusion, recent surgery

(c) Disease related-poorly controlled diabetes, cancer, leukemia, alcoholic cirrhosis, end-stage renal diseases

(d) Compromised immunity-multiple myeloma, total body irradiation, splenectomy

(e) Immunosuppressants-cytotoxic drugs, glucocorticoids, azathioprine, cyclosporine

2. Potential for bacterial contamination of a sterile field

3. Procedures with high infection rate

4. Surgical procedures in which there is a high mortality / morbidity rate following infection

5. When a foreign body is inserted into the tissues

Table 10.5 Classification of surgical wounds

\begin{tabular}{|l|l|l|} 
Type & $\begin{array}{l}\text { Incidence of } \\
\text { infection (values } \\
\text { given for general } \\
\text { surgical cases) }\end{array}$ & $\begin{array}{l}\text { Examples for the types of } \\
\text { surgical wounds in } \\
\text { maxillofacial surgery }\end{array}$ \\
\hline $\begin{array}{l}\text { Temporomandibular joint } \\
\text { surgery, facial cosmetic } \\
\text { surgery }\end{array}$ \\
\hline $\begin{array}{l}\text { Clean- } \\
\text { contaminated } \\
\text { Contaminated }\end{array}$ & $3-11 \%$ & $\begin{array}{l}\text { Orthognathic procedures, } \\
\text { extractions } \\
\text { Maxillary fracture with active } \\
\text { maxillary sinusitis } \\
\text { Dirty wound } \\
\text { an infected third molar socket }\end{array}$ \\
\hline
\end{tabular}

Table 10.6 Need for postoperative antibiotics

\begin{tabular}{|l|l|}
\hline 1 & Compromised immunity \\
\hline 3 & Inflammation at the surgical site \\
\hline 4 & Evidence of wound dehiscence \\
\hline 5 & Active periodontal disease \\
\hline 6 & Poor oral hygiene \\
\hline 7 & Inadequate surgical skill \\
\hline 8 & Prolonged surgery \\
\hline
\end{tabular}

3. The selected antibiotic should be bactericidal against the most common microorganisms that cause infection in the oral cavity. The bactericidal antibiotics rely less on the host defense mechanisms providing faster results [18].

4. The concentration of antibiotics in the tissue should be sufficient to fight the bacteria that may enter the surgical wound at incision or during the course of surgery. To achieve a blood concentration of three-four fold that of minimum inhibitory concentration, the antibiotic is typically given at twice the treatment dose $1 \mathrm{~h}$ prior to surgery $[14,16]$.

5. Usually antibiotics can be administered as a single preoperative dose. In cases where the surgeon feels that postoperative infection is a high possibility, the drug can be extended postoperatively as deemed necessary [19] (Table 10.6). 
One must be vigilant in identifying cases where antibiotics are required for the success of surgery, as antibiotic usage and overusage have considerable risks [6, 7, 20, 21]-gastrointestinal disturbances, toxicity reactions, antibiotic resistance and superinfections, anaphylaxis, pseudomembraneous colitis, etc.

\subsubsection{Prophylactic Uses of Antibiotics in Maxillofacial Surgery}

Infection, one of the most common postoperative complications, can be prevented by the timely use of appropriate antibiotic. In spite of many studies in literature, a definitive conclusion cannot be made regarding the need for antibiotic prophylaxis in maxillofacial surgery and, if needed, the dose required. The antibiotic prescription pattern is still hugely based on personal preferences and shows wide regional variation, which many a time is inappropriate. The drugs would be initiated either at an incorrect time, or would be continued beyond the time required, and this has greatly contributed to the emergence of resistant bacteria [6].

Prophylactic use of antibiotics should be evidence based taking into consideration the effectiveness and the possible adverse outcomes of antibiotic therapy. Moreover, a thorough knowledge of the likely organisms involved in the infection is needed to prevent the prescription of unsuitable antibiotics. Antibiotics, if needed, should have a spectrum of activity that involves streptococci, anaerobic Grampositive cocci, and anaerobic Gram-negative rods, which are considered the most pathogenic for oral infections and should be bactericidal and the least toxic agents available amoxicillin being the most common choice of the clinicians $[12,18]$.

The need for antibiotic prophylaxis and the preferable drugs for wisdom teeth removal, orthognathic surgery, dental implants, maxillofacial trauma, and in special circumstances like patients with diabetes mellitus, patients-pre- and postorgan transplant, rheumatic heart disease-valve replacements, oncological surgery \& reconstruction, cleft surgeries, etc. are mentioned in the following sessions.

\subsubsection{Antibiotic Prophylaxis in the Surgical Removal of Wisdom Teeth}

Though one of the most commonly performed minor oral surgical procedures, the reported infection rate with the removal of mandibular third molars is $\leq 10 \%$ [22]. However, the rate can be as high as $25 \%$ when the patient's immunity is compromised [20]. The infection rate associated with the corresponding procedure in maxilla is quite low, $<1 \%[20$, $22]$. The higher rate of postoperative infection in relation to mandibular third molar has been attributed to the reduced vascularization and the gravity-induced pooling of bacterialrich saliva.

The prophylactic use of antibiotics in wisdom teeth removal had been an issue of many debates. There are studies for [20, 23] and against [24, 25] the practice of antibiotic prophylaxis in third molar removal. Considering the potentially contaminating oral environment in which the third molar removal is carried out, it is reasonable to favor antibiotic prophylaxis. Moreover, since the postoperative infection and alveolar osteitis, an inflammatory response whose etiology could be traced to bacterial contamination and fibrinolysis of the socket blood clot, cause debilitating pain and severe functional impairment, it is only prudent to consider the use of prophylactic antibiotics.

Studies have shown that preoperative administration of antibiotics reduces the postoperative infection when administered 1-2 $\mathrm{h}$ prior to the procedure [26, 27]. Amoxicillin/ amoxicillin — clavulanic acid is the widely used antibiotic in the prophylaxis for the surgical removal of impacted teeth [28] and when given as a single dose preoperatively is found to reduce postoperative infection and alveolar osteitis [21]. But certain other studies have failed to show a considerable difference between amoxicillin, clindamycin, metronidazole, and placebo in terms of postoperative infection rates [25]. Studies have found topical tetracycline [29], chlorhexidine irrigation [30],\& metronidazole dressings [31]into the mandibular third molar sockets, effective in reducing the postoperative infection \& the incidence of dry socket. Review of literature does not give definite indication to use of antibiotics as prophylaxis in healthy patients or asymptomatic impacted teeth and in case of the removal of maxillary wisdom teeth [22].

Studies have advocated the use of antibiotic prophylaxis in immunocompromised patients to prevent infection after surgical removal of impacted teeth [22].

Two recent meta-analyses $[28,32]$ summarize the antibiotic prophylaxis in wisdom teeth removal (Table 10.7).

\subsubsection{Antibiotic Prophylaxis in the Placement of Dental Implants}

Dental implants play a crucial role in the successful restoration of missing dentition. The success rate of dental implants is high, with only $0-10 \%$ of reported failure rates [33]. However, risk of failure is high during the first year after implant placement [34]. The implant surfaces can become colonized by oral and perioral microorganisms during surgery (perioperative contamination) [35]. This can lead to pain, swelling, bone loss, and eventually failure of implants. The failure of the dental implants is multifactorial (Table 10.8). 
Table 10.7 Antibiotic prophylaxis in wisdom teeth removal-Key points

1 Factors influencing the rate of postoperative infection [20,32] may need to consider postoperative antibiotics

History of pericoronitis

Smoking

Old age

Poor oral hygiene

Duration of surgery

Amount of bone removal

Presence of foreign bodies - hemostats or devitalized bone fragments

Operator skill

2 Amoxicillin \& Amoxicillin—clavulanic acid equally effective [28]

3 Systemic administration more effective [32]

4 Single preoperative dose: $30-90 \mathrm{~min}$ prior to procedure [18, 32]

5 Usually double the usual strength is given preoperatively $[18,26]$

6 Antibiotics reduce incidence of alveolar osteitis [21].

7 Topical tetracycline [29], chlorhexidine [30], \& metronidazole [31] effective in reducing the infection rate

8 Preoperative and extended postoperative doses may be required in immunocompromised patients [22]

9 No antibiotic prophylaxis required in removal of asymptomatic mandibular third molars and maxillary third molars in healthy individuals [22]

Table 10.8 Factors affecting the survival of implants [33, 34]

\begin{tabular}{|c|c|}
\hline Local factors & $\begin{array}{l}\text { 1. Pre-existing infections } \\
\text { 2. Quality \& quantity of bone } \\
\text { 3. Bone grafts-autogenous vs allogenic } \\
\text { 4. Ill-fitting prostheses } \\
\text { 5. Bad oral hygiene } \\
\text { 6. Irradiated bone }\end{array}$ \\
\hline Systemic factors & $\begin{array}{l}\text { 1. Immunocompromised diseases } \\
\text { 2. Diabetes } \\
\text { 3. Long-term steroids } \\
\text { 4. Malnutrition } \\
\text { 5. Elderly patients } \\
\text { 6. Smoking }\end{array}$ \\
\hline Surgical factors & $\begin{array}{l}\text { 1. Incorrect instruments } \\
\text { 2. Overheating during placement } \\
\text { 3. Lack of attention to sterility. } \\
\text { 4. Increased duration of the procedure [20] } \\
\text { 5. Operator skill [20] }\end{array}$ \\
\hline
\end{tabular}

Hence all these local, systemic, surgical, and procedural factors contributing to implant failure should be eliminated before considering infection as the reason for failure [33].

Because of the morbidity associated with infection of the implants, antimicrobial therapy is routinely used with the aim of prevention of surgical site infection. Though by definition, dental implant placement is a clean-contaminated surgery with $3-11 \%$ chances of infection, the infection rate can be brought down to about $1 \%$ by proper patient selection, attention to surgical details, and by judicious use of antibiotics [18].

There are studies supporting antibiotic use to reduce implant failures $[33,34]$ and studies that fail to show any added benefits of antibiotics against implant failurte [36]. Few other studies have observed similar failure rates for the implants with a single preoperative dose and routine use of antibiotic for 7 days [37].

The currently advocated dose of antibiotic prophylaxis for implant surgery is $2-3 \mathrm{~g}$ of amoxicillin $2 \mathrm{~h}$ prior to multiple implant placement, especially along with bone graft [33]. If the patient is allergic to penicillin group, $600 \mathrm{mg}$ clindamycin should be given $1 \mathrm{~h}$ before surgery. For sinus augmentation, $1.2 \mathrm{~g}$ of amoxicillin/clavulanic acid starting day before the surgery is the prophylaxis of choice [33]. Chlorhexidine gluconate mouth rinses have been known to reduce the number of pathogenic microorganisms, by lysing the bacterial cell membranes, and by virtue of its substantivity, can get retained in the oral soft tissues and get released slowly for up to $12 \mathrm{~h}[30,33]$. The key points in the antibiotic prophylaxis for dental implants are given in Table 10.9.

\subsubsection{Antibiotic Prophylaxis in Orthognathic Surgery}

Orthognathic surgical procedures aim to correct the facial deformities and malocclusion, thereby improving the functional disorders of the stomatognathic system. It is an elective procedure, usually carried out in young healthy adults. It is considered as a clean-contaminated procedure with a reported infection rate of $3-11 \%[18,39]$. But certain studies have reported the rate of infection after orthognathic surgery to be as high as $6-33.4 \%$ [39]. The postoperative infection was found to be related to poor oral hygiene and the habit of smoking.

The surgical site infections (SSIs) that develop can be incisional SSIs and organ and space SSIs [40]. Both types of SSIs can occur after orthognathic surgery and may develop within the first few weeks after surgery. The development of SSIs increased the total length of hospital stay and expenditure. Though the potential for postoperative infections after orthognathic surgery is known for a very long time, a consensus has not yet been achieved with regard to the drug that is useful, the dose, and the duration of administration.

The specific orthognathic procedure that has been associated with higher infection rate was mandibular sagittal split osteotomy, especially where a transbuccal approach had been adopted for fixation [38]. Increased rate of infection associated with mandibular procedures has been attributed to the diminished vascularity of mandible in comparison with maxilla and pooling of food and saliva along the vestibular incision line in the mandible. Till the incision seals off, oral microflora can freely enter the deeper tissues from the pooled saliva. Though concomitant extractions, especially of partially erupted mandibular third molars had been implicated as a risk factor for the development of postoperative infec- 
Table 10.9 Antibiotic prophylaxis in dental implants-Key points

Care to be taken [35]:

Through oral prophylaxis \& measures to improve oral hygiene

Stabilize oral focus of infection

Procedure in a well-monitored asceptic environment-

disinfection, draping, hand scrubbing, sterile gowns \& gloves, sterile instruments

Prevent contamination of implants with contact with skin, infected oral mucosa, \& sinus lining

Bactericidal antibiotic with coverage against pathogenic oral microflora $[12,18,33]$

Preoperative administration of antibiotics $-1 \mathrm{~h}$ before the procedure, twice the therapeutic dose $[18,33]-$ Amoxicillin $2 \mathrm{gm}$, / clindamycin $600 \mathrm{mg} 1 \mathrm{~h}$ prior to surgery

Chlorhexidine gluconate rinses-hugely effective in controlling the immediate local infection [30, 33].

1 Only Chlorhexidine $0.12 \%$ rinse twice daily in healthy individuals [33]

(a) Simple implant,

(b) Short duration,

(c) No bone graft,

(d) Sterile environment is ensured..

2 Single preoperative dose + Chlorhexidine $0.12 \%$ rinse twice daily in healthy individuals [33]

(a) Multiple implants with minimal tissue reflection,

(b) Immediate extraction \& implant placement,

(c) Socket bone grafting.

3 Single preoperative dose +3 doses / day X 3 postoperative days + Chlorhexidine $0.12 \%$ rinse twice daily in healthy individuals [33]

(a) Multiple implants with extensive tissue reflection,

(b) Multiple extractions \& implant placement,

(c) Bone grafting - allografts,

(d) Long duration.

4 Single preoperative dose +3 doses / day X 5 postoperative days + Chlorhexidine $0.12 \%$ rinse twice daily [33]

(a) In medically compromised patients,

(b) Extensive tissue reflection,

(c) Full arch implants,

(d) Block bone grafting-autografts,

(e) Indirect sinus floor lift procedures,

(f) Active periodontal disease.

5 Loading dose on the previous day +3 doses / day X 5 postoperative days + Chlorhexidine $0.12 \%$ rinse twice daily [33] In sinus lift procedure

tion, studies were not able to support or refute this $[38,41]$ Longer surgeries involving multiple/segmental procedures also show a higher rate of infections [12, 18, 38].

Use of various antibiotics has been proposed-penicillin [42], ampicillin [43], amoxicillin with or without clavulanate [43], clindamycin [42], or a member of the cephalosporin group $[19,41]$. Literature fails to report a significant difference in the infection rate when using a penicillin or nonpenicillin group of antibiotics or among the various types of penicillins $[18,19,44]$. Based on the bacteriological studies, penicillin, amoxicillin, or amoxicillin-clavulanic acid or cephalosporins is commonly recommended in the preoperative antibiotic prophylaxis for orthognathic surgery [19, 38, 41-44].
The preoperative single dose of antibiotic increases the level of the drug in circulation prior to incision. Whether short-term antibiotics (single dose or dose $\times 24 \mathrm{~h}$ ) [ 42] or extended-term antibiotics (for more than $24 \mathrm{~h}$ ) [ 41, 43] is beneficial in the prevention of postoperative infection after orthognathic surgery is still a debatable question $[19,38$, $41,44]$.

\subsubsection{Is Antibiotics Needed when Bone Plates and Screws Are Being Inserted?}

One question that keeps on surfacing is whether prophylactic antibiotics are needed in cases where bone plates and screws are used to hold the bony segments together. Any foreign body inserted into the body, be it a medical device or implant, may elicit a foreign body reaction. Moreover, the microorganisms can colonize on the implant surface in a biofilm, while they are being inserted, and as the physical presence of the implants may compromise the blood supply to the region, thereby reducing the delivery of body's immune cells to the region and resulting in infections at the host -implant interface by normal flora with low virulence [45, 46]. The oral biofilm and its toxins, adhered to the surface of titanium plates and screws used for stabilization of osteotomy segments, could be a source of local or regional infectious complications [19]. Hence, the use of antibiotic prophylaxis is justified.

Take-home points regarding antibiotic prophylaxis in orthognathic surgery are mentioned in Table 10.10.

\subsubsection{Antibiotic Prophylaxis in Maxillofacial Trauma}

In today's world of fast-moving vehicles and expressways, hundreds of thousands of people get involved in road traffic accidents. Head and face are among commonly injured body parts. Both the soft and hard tissues of the face may be involved in the trauma. Firearms, contact sports, and interpersonal violence are other reasons for facial injuries. The management of these injuries should follow protocols and be done in a systematic manner. With advances in anesthetic and surgical techniques and availability of better implant materials with favorable metallurgy, open reduction and internal fixation (ORIF) has become the norm. The reestablishment of form, function, \& cosmesis is of paramount importance. To arrive at this goal, the probable complications of ORIF need to be prevented or managed correctly. Of the various complications reported, none has generated more interest and controversy than the occurrence of postoperative infection. By adhering to the standard surgical protocols and strict aseptic techniques, the occurrence of postoperative 
Table 10.10 Antibiotic prophylaxis in orthognathic surgery-Key points

1. Risk factors for SSIs [47, 48]

(a) Longer surgery;

(b) Short-term antibiotic prophylaxis;

(c) Extraction of a third molar during surgery;

(d) Greater number of osteotomies performed;

(e) Older age;

(f) Smoking;

(g) Poor oral hygiene;

(h) Compromised immune system.

2 Orthognathic surgery - clean-contaminated wound-with the osteotomized maxilla / mandible exposed to oral / nasal / antral cavities [48].-Antibiotics needed

3 Need for antibiotics in presence of bone plates \& screws [45, 46].

4 Loading dose of double strength $1 \mathrm{~h}$ prior to incision [18].

5 Confusion between - single loading dose + short-term doses $x$ $24 \mathrm{~h}$ vs long-term antibiotics for more than $24 \mathrm{~h}[19,44]$. Commonly isolated organisms - aerobic bacteria—streptococci $(43 \%) \&$ anaerobic bacteroides $(50 \%)[18,39]$

6 Amoxicillin / amoxicillin—clavulanic acid—best suited [19, 42-44].

7 Higher infection rate-mandibular osteotomies with transbuccal approach for fixation [38].

8 Longer procedures \& segmental osteotomies-more prone for infection [38].

9 Concomitant removal of mandibular third molars does not increase the risk for postoperative infection [39], though may cause issues with fixation.

infection can be brought down considerably. But the presence of the microorganisms in the oral cavity and facial skin and possible contamination from environment necessitate the consideration of antibiotics in the maxillofacial trauma management.

Though prophylactic antibiotics were considered essential in the management of maxillofacial trauma for many years [18], the evidence for this preventive intervention was weak and confusing. Among facial fractures, mandibular fractures are most commonly studied, because of the compound nature of the fractures, except in the ramus - condyle unit, where the fractures usually do not communicate with the external environment. Fractures of the mandibular condyles or Lefort fractures of maxilla are rarely infected when compared with the fractures involving mandibular angle, body, or symphysis $[49,50]$.

The decision to use antibiotic prophylaxis depends on whether the fracture is an open or closed type and whether it is going to be managed with open or closed reduction. Open procedures were four times more commonly prone to postoperative infections according to a few studies [41, 51, $53,54]$, whereas certain other studies reported no difference between the patients treated with closed reduction and maxillomandibular fixation and those who underwent open reduction and internal fixation [54]. The microbiology of the infected fractures was mixed and responded to betalactam antibiotics well.
Table 10.11 Antibiotic prophylaxis in maxillofacial trauma-Key points

1. Risk factors for SSIs $[22,32,51,56]$

(a) Longer surgery;

(b) Older age;

(c) Smoking;

(d) Poor oral hygiene;

(e) Compromised immune system.

2 Mandibular fractures/ fractures of the teeth-bearing area-open / compound fractures.-Antibiotics needed [49, 50, 53, 54].

3 Need for antibiotics in presence of bone plates \& screws [45, 46]

4 Loading dose of double strength $1 \mathrm{~h}$ prior to incision $[18,56]$.

5 Beta-lactam antibiotics-preferred [56].

6 Higher infection rate-in fractures involving mandibular teeth-bearing areas [49]

7 Longer duration of antibiotics in immunocompromised patients $[49,52]$.

8 Chances of infection more with open reduction than in those treated with closed reduction with no antibiotic prophylaxis [16, 50, 51]. But with single dose of perioperative antibiotics, no significant difference between closed \& open reduction [51, 54]

10 Delayed healing and increased infection rate with tobacco smoking [51].

Studies have shown that single dose of preoperative antibiotic prophylaxis is sufficient to prevent wound infection $[51,54]$. If the surgery extends beyond the half-life of the antibiotic, the antibiotic can be redosed [51]. The need for postoperative antibiotics in the maxillofacial trauma too has been extensively studied $[16,49,53,55,56]$. These studies reported no statistically significant difference in the development of SSIs between the patients who had received perioperative antibiotics and those who had received extended antibiotics in the postoperative period.

Longer antibiotic usage has been advocated in the immunocompromised patients $[32,52,56]$. The habit of tobacco smoking was found to have a deleterious effect on the healing of mandibular fractures by inducing hypovascularity and prolonged inflammation [54]. The other major factors, which contribute to the occurrence of SSIs, are poor oral hygiene, extremes of age and malnutrition [22,32].

Important points mentioning the need for antibiotics in the management of maxillofacial trauma are given in Table 10.11 .

\subsubsection{Diabetes Mellitus \& Antibiotic Prophylaxis in Maxillofacial Surgery}

Diabetes mellitus is a metabolic disorder resulting in elevated glucose levels, due to inadequate insulin secretion (type I) or reduced insulin secretion with an accompanying insulin resistance (type II). Diabetic patients pose a special challenge to the surgeon as the balance between the insulin they can secrete and the hyperglycemia induced by surgical stress-adaptive hormones catecholamines, cortisol, growth 
hormone, and glucagon is lost. Patients, who are nondiabetic, usually are able to handle this glucose overload effectively, whereas diabetic patients may have issues resulting in cardiovascular complications, infection, and reduced rates of wound healing. Moreover, the defective polymorphonuclear leukocytes function and macro- and microvascular dysfunction resulting in compromised local circulation increases the susceptibility to infections [57]. With the vast microbiological colonization of the oral cavity, it has always been assumed that maxillofacial surgical procedures carry a high risk of infection and prolonged or delayed wound healing. The guidelines as to the prophylactic use of antibiotics in diabetic patients had been vague as ".....are more prone to infection necessitating routine antibiotic prophylaxis for all maxillofacial procedures" [58].

In many of the literature surveys, authors have noted that well-controlled diabetic patients are at no increased risk of postoperative infection than normal healthy patients and delayed wound healing is not a pressing concern due to the rich vascularity of the region $[59,60]$. Antibiotic prophylaxis is warranted only in conditions where a normal patient also would benefit from it. Poorly controlled diabetic patients would require normalization of their hyperglycemic state prior to elective procedures. In emergency situations, antibiotic prophylaxis prior to the surgical incision is desirable and attempts should be made to control the glycemic level during the peri- and postoperative period [58-60].

\subsubsection{Antibiotic Prophylaxis in Head and Neck Oncology}

Head and neck oncology patients usually require a major surgical procedure $+/-$ with radiation therapy. The surgical site tends to be large, the surgical time and postoperative immobilization period longer. The surgical management attempts at removal of the tumor, clearance of the neck nodes, and involves an additional surgical site from where flap is harvested for reconstruction-either microvascular flaps or pedicled ones [61]. The large wound area exposed to local flora of the oral cavity and the skin is at risk of wound contamination and infection. Nosocomial infections are known to run a protracted course and pre-existing general comorbidities further increase the morbidity and, thus, the hospital expenses associated with these surgeries.

The reasons for increased infection rate are mainly the number of procedures carried out in the same operation (excision, neck dissection, tracheostomy, and distant flap harvest), the pooling of saliva due to difficulty in swallowing, leading to aspiration, and the inability in obtaining a watertight closure when the flap is inset in the recipient bed leading to salivary leak and contamination of neck wounds with saliva $[62,63]$.
Table 10.12 Key points in oral oncology \& antibiotic prophylaxis

Increased risk of SSIs [62]

Multiple procedures done at a single operation,

Large wound area,

Long procedure,

Tobacco \& alcohol abuse

Immunocompromised patients

Probable pathogens [62] - Escherichia spp. \& staphylococcal spp

Preferred antibiotic [62] - ampicillin \& sulbactum

Bartella et al. (2017) [62] - Statistically significant reduction in

infectious complications with postoperative antibiotics

The need for antibiotic prophylaxis is well established in the oncologic surgery, but the need for a long postoperative course of antibiotics is still debated upon. There are studies, which have shown benefits of prolonged antibiotics in preventing postoperative infections like pneumonia, urinary tract infections, sepsis, and SSIs in patients who had oral squamous cell carcinoma [64], and there are studies, which have shown no extra benefits of prolonged postoperative antibiotics [63, 64].

Escherichia spp. and Staphylococcus spp. are predominantly responsible for the infections and in $72 \%$ were sensitive to ampicillin \& sulbactum [62].

A few key points, which would be beneficial in making a decision, are given in Table 10.12.

\subsubsection{Antibiotic Prophylaxis in Cleft Surgeries}

Orofacial clefting is one of the more common congenital anomalies and cleft lip \& palate deformity is the most common among them. Management of cleft lip \& palate deformity involves staged procedures and spans over 12-16 years. The management aims at correction of the deformity so that function and cosmesis are restored as much as possible and the psyche of the individual is minimally scarred. Postoperative infections can result in wound breakdown, poor speech \& esthetics, and nasal regurgitation of food in cleft lip and palate patients.

Various authors had reported on obtaining swabs from nose and oral cavity to identify the possible pathogens and using antibiotics according to the culture reports before cleft lip and palate repair [65-67]. The pathogenic bacteria isolated from the swabs were Staphylococcus aureus and beta hemolytic streptococci [67]. But later studies demonstrated that there were not many differences between the group that underwent swab acquisition and corresponding antibiotics therapy and the group that didn't receive any antibiotics in terms of postoperative complications [68]. The rate of complications was found to be independent of the potential pathogens in the mouth [65].

Factors, which have been implied as contributing factors to wound dehiscence, are given in $[66,67]$ Table 10.13. 
Table 10.13 Factors contributing to wound dehiscence in cleft surgeries

\begin{tabular}{l} 
Wide clefts \\
Closure under tension \\
Bilateral clefts \\
\hline Long duration of surgery \\
Poor technique-traumatized nasal mucosa \\
Independent of potential oral pathogens
\end{tabular}

In a recent prospective study, Azner et al. (2015) noted a statistically significant reduction in the incidence of palatal fistulas with 5 days of postoperative antibiotics [69]. But $80 \%$ of their control group, who had received no postoperative antibiotics, too healed without any complications. Both study and control groups had received a single dose of cefuroxime $30 \mathrm{mg} / \mathrm{kg}$ body weight, before incision. The use of one dose of antibiotics before incision has been advocated by other authors also and may be more effective in preventing complications related to wound infection than a prolonged course of postoperative antibiotics [68].

\subsubsection{Organ Transplant and Antibiotic Prophylaxis}

The concept of organ donation had always excited mankind. Twentieth century saw developments that made the dream of replacing a diseased organ with a healthy one a reality. Understanding the human immunology and the development of powerful immunosuppressant drugs laid the foundation for modern transplant medicine, making transplantation of kidney, liver, lungs, and heart a successful treatment option. As the transplant science advanced, so did the numbers and life span of transplant patients and their need for dental/maxillofacial surgical procedures. As these patients are on immunosuppressants, they are more prone to opportunistic infections and their sequel. Hence, care must be given to treat or remove the existing/potential sources of infection before the transplant procedures.

In a pretransplant patient, the need for maintaining oral hygiene should be stressed upon. The treating physician should be consulted with regard to the fitness to undergo the planned procedures and the safety of using any drugs if required. Drugs, which have a hepatic metabolism or renal clearance, should be used with caution in patients with compromised liver or kidney function. The selection of antibiotics is made after careful evaluation of the existing pathology and the chances of spread of infection with the planned dental treatment.

In the immediate post-transplant period-the first 3 months post-surgery, the graft, and the patient are very vulnerable to any insult-graft anastomoses are susceptible to endarteriris due to bacterial colonization as they are not yet
Table 10.14 Key points—organ transplant and antibiotic prophylaxis Pretransplant patients-stress on

1. Elimination of potential focus of infection,

2. Oral hygiene,

3. Liver / kidney friendly drugs.

Post-transplant patients:

Immediate postop:

1. Only emergency procedures,

2. Aggressive management of infections.

3 months postop-noninvasive elective procedures 6 months postop-invasive elective procedures under antibiotics Beta-lactam antibiotics - relatively safer to be used in renal and hepatic transplant patients [72]

No consensus on minimally invasive procedures in patients with meticulous oral hygiene [71]

fully epithelialized. Hence, only emergency procedures should be done. Any acute orofacial infection developing should be managed aggressively, surgical drainage, culture and sensitivity of the organism, and appropriate antibiotics would be required [70]. After 3 months, elective, noninvasive procedures can be carried out. Since the patients who have undergone organ transplantation are immunosuppressed and are at high risk of infection, prophylactic antibiotics need to considered for any invasive dental procedures, even after 6 months. Beta-lactam antibiotics are relatively safer to be used in renal and hepatic transplant patients [71]. But for those with meticulous oral hygiene, there is no consensus regarding the need for antibiotic prophylaxis for minimally invasive procedures [71]. The decision to use antibiotics should be done on a case-to-case basis.

Important points to be kept in mind while contemplating antibiotic prophylaxis in organ transplant patients are given in Table 10.14.

\subsection{Infective Endocarditis}

Bacterial endocarditis, a rare but life-threatening condition, was initially described by Lewis \& Grant in 1923 [72]. They suggested that bacteria released into the blood stream after a dental procedure colonize on the heart valves or the endocardium. The bacteremia associated with infections of skin and soft tissues, genitourinary tract, and gastrointestinal tract are also known to result in infective endocarditis (IE). Bacteria can gain direct access to the bloodstream through the indwelling catheters. The American Heart Association (AHA) came up with the first guidelines to reduce the risk of IE following invasive procedures in 1955 [73]. The AHA guidelines have been updated regularly since then and the latest one was released in 2007 [74]. The 2007 guidelines categorized cardiac conditions into having a low risk, moderate risk, and high risk of developing IE and advocated the use of antibiotic prophylaxis only in 
Table 10.15 High-risk cardiac conditions, which require antibiotic prophylaxis [75]

Prosthetic cardiac valves

Congenital heart diseases - unrepaired, with palliative shunts or conduits or repaired with prosthetic material or those repaired, but with residual defects

Previous IE

Cardiac transplants who have developed valvulopathy

high-risk-category patients (Table 10.15) who were to undergo dental procedures that involved the manipulation of gingival tissues or the periapical region of teeth or incision of the oral mucosa.

The guidelines prescribed a single dose of antibiotic 30-60 minutes prior to the procedure-Amoxicillin $2 \mathrm{~g}$ PO, Cephazolin/Cephtriaxone 1gm IV/IM, or Clindamycin $600 \mathrm{mg} \mathrm{PO} / \mathrm{IM} / \mathrm{IV}$, depending on whether the patient is unable to take oral preparations or is allergic to penicillin or not [74]. The reason for the revision of the antibiotic policy was predominantly the observation that IE is more likely to result from transient bacteremias caused by routine daily activities, like chewing food, and by regular oral hygiene care. The authors concluded that maintaining optimal oral hygiene is more important in reducing the risk of IE and the adverse effects of antibiotics exceeded the benefits of antibiotic prophylaxis. The British Society for Antimicrobial Chemotherapy (BSAC) also recommend antibiotic prophylaxis only in those who have a history of healed IE, prosthetic heart valves, and surgically constructed conduits [75]. The advice to the patient is to concentrate on achieving and maintaining meticulous oral hygiene as this has been found to reduce the risk of IE. Similar observations were made by the National Institute for Health and Care Excellence (NICE) [76] and the European Society of Cardiology (ESC) [77].

There has been a rising concern over the potential for an increased incidence of IE and a worse prognosis for the diseased since the guideline changes by the AHA, NICE, ESC, BSAC. Several studies have been carried out to assess the impact of these changes on the disease incidence in adults and pediatric population. Whereas earlier studies showed not much difference pre- and post-guideline changes in incidence [78], recent studies have noted a definite increase in the incidence of IE post-guideline changes [79]. Sakai et al. in 2017, though noting no change in the incidence and severity of IE in pediatric patients, pre- and post- guideline changes, reported an increase in the viridans group streptococci (VGS)-induced IE in older age group [79]. The data from these studies point to the need for further investigation into the effectiveness of 2007 guidelines, though it has been argued that the increase in IE incidence may be related to the increasing life span of the patients with congenital heart diseases and prosthetic devices and increase in the number of invasive procedures being performed on them.

\subsection{Postoperative Pain Management in Maxillofacial Surgery}

The International Association for the Study of Pain (IASP) defines pain [80] as: "an unpleasant sensory and emotional experience associated with actual or potential tissue damage or described in terms of such damage."

Pain is the most debilitating postoperative symptom and its control or elimination is usually the primary goal in postoperative management of a patient. Inadequate pain control resulting in patient distress is the most common cause of an increased length of hospital stay. The postoperative pain, inflammatory in character, is a temporary one persisting only until healing. But severe, acute, repetitive, postoperative pain increases the risk of the pain becoming chronic and may lead to allodynia and hyperalgesia [81]. Orthognathic surgery patients may continue to feel the pain even after 1 year of surgery [82] Hence, appropriate pain management is critical to achieving a successful surgical outcome. Prevention of pain is more efficient than the treatment of pain. For this, an understanding of basic pathophysiology behind pain mechanism is important.

\subsection{Pathophysiology of Postoperative Pain}

Pain is initiated by the excitation of nociceptors, receptors that respond to noxious - mechanical, thermal, and chemical stimuli. Sensory nociception is disproportionately greater in the head and oral cavity when compared with other parts of the body. Often a patient's overanxiety about undergoing an elective surgery would result in an increased intensity of the perceived pain [83].

Surgical insult results in tissue trauma and initiates a chain of inflammatory events, causing a release of chemical substances responsible for nociceptor excitation. Trauma releases tissue phospholipids, which are converted into arachidonic acid due to the action of phospholipase A2 and the consequent conversion of this substance into prostaglandins, prostacyclins, and leukotrienes due to the action of cyclooxygenase (Cox) and lipoxygenase enzymes. These locally released chemical mediators sensitize the nociceptors and cause vasodilatation, with a consequent increase in cell permeability and edema. Trismus after a maxillofacial surgery is a sequela to the postoperative edema around the masticator muscles and is aggravated by pain [84]. The physiological responses to tissue trauma, pain \& edema, can be managed successfully by inhibiting the pathways that produce the chemical mediators, before the occurrence of surgical trauma (Fig. 10.1)

Similarly, mechanisms, which enhance the endogenous pain inhibition and anxiolysis and patient education, can 


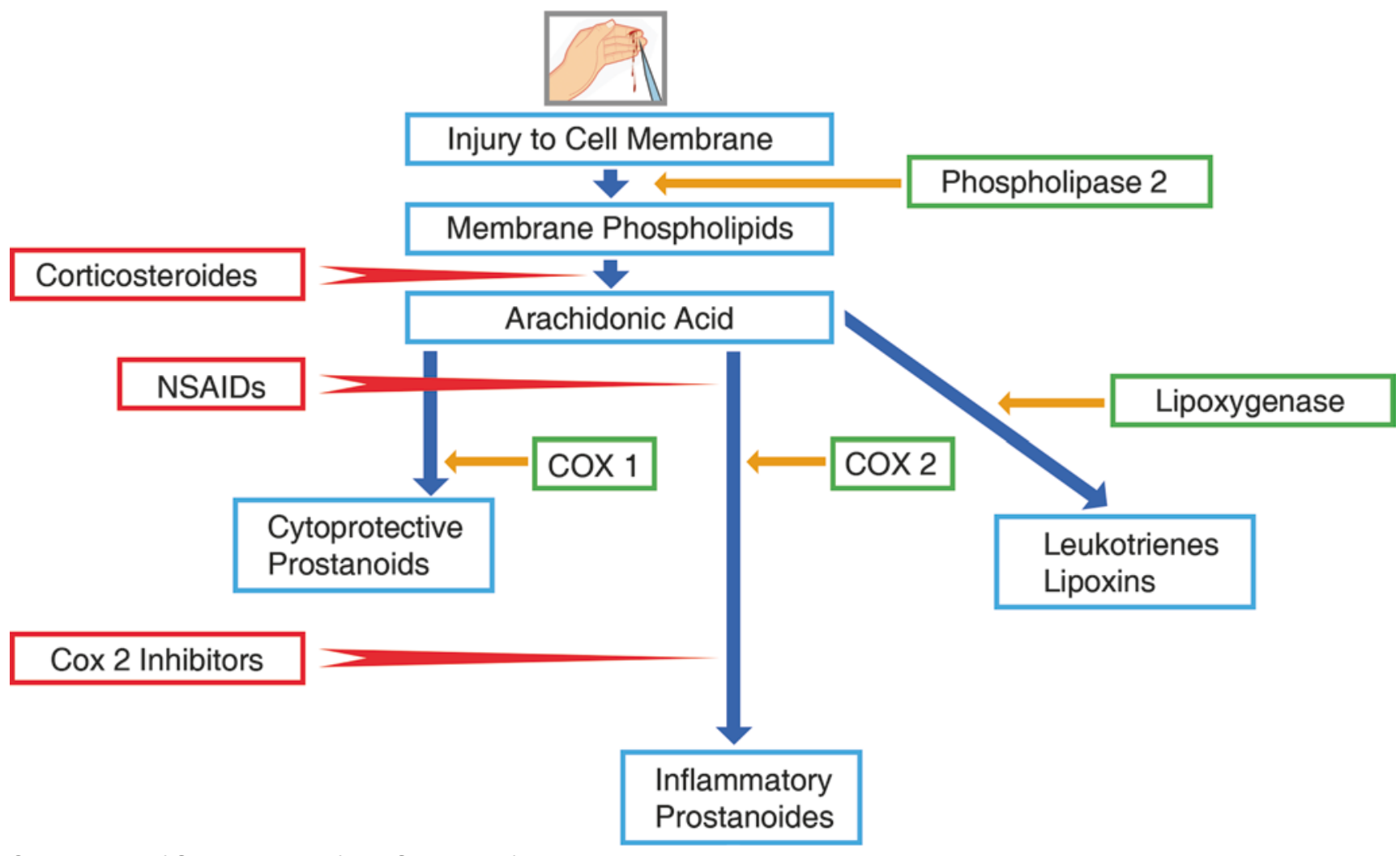

CAssociation of Oral and Maxillofacial Surgeons of India

Fig. 10.1 Pharmacologic interventions in arachidonic acid metabolism

modify cortical processing of pain perception [85]. All these measures collectively lead to an efficient postoperative pain management.

\subsubsection{Pre-Emptive Analgesia}

Postoperative pain has a protective function as it allows for undisturbed healing of the operated tissue by restricting movements. The aim of postoperative pain management is to reduce pain significantly, but not to eliminate it completely [86]. Overall postoperative pain experience could be reduced by paying attention to lessening of the pain during the surgical procedure itself. Pre-emptive analgesia is defined as an antinociceptive treatment that is started preoperatively and is active during surgery, reducing the physiological consequences of nociceptive transmission [87]. Since the introduction of the concept of pre-emptive analgesia by Woolf in 1983, many attempts to reduce the pain by using analgesics and adjunctive measures, such as the administration of long-acting local anesthesia, corticosteroids, and intraoperative nitrous oxide analgesia, have been reported [88]. These should be given before the surgical incision and should be timed so that the maximum plasma concentration of the drug is reached at the time of surgical incision. This will prevent the release of the inflammatory mediators, giving immediate analgesic effects. The use of IV analgesia has an added benefit over oral administration, as following oral administration analgesics reach maximum concentration after $1.5 \mathrm{~h}$, whereas intravenous administration results in maximum concentration in a short period.

Numerous studies have shown beneficial effects of the preoperative administration of ibuprofen with paracetamol [89] piroxicam [90], ketorolac [91], meloxicam [92], parecoxib [93], and dexamethasone with rofecoxib [94]. There had been contradictory reports also in which the authors fail to find a clear-cut benefit for pre-emptive NSAIDS [95, 97]. The authors state that the pre-emptive intake of analgesics should not be used in all patients as a general rule. They base their recommendations on the lack of enhanced analgesic effects and on the potential adverse effects such as increased intraoperative bleeding [95].

Despite the confusion regarding the effectiveness of the pre-emptive analgesia, it has been strongly advised to start systemic analgesics before the local anesthesia effect wears off and/or give a nerve block with long-acting agent like bupivacaine [86]. 
Table 10.16 Predictors of postoperative pain

\begin{tabular}{|l|l|}
\hline Patient-related factors & $\begin{array}{l}\text { Surgical indicators } \\
\text { Major surgeries-long } \\
\text { duration }\end{array}$ \\
\hline Female sex [98] & $\begin{array}{l}\text { Bony surgery > soft tissue } \\
\text { surgery [100] }\end{array}$ \\
\hline $\begin{array}{l}\text { Anxiety \& apprehension, fear of the } \\
\text { procedure }\end{array}$ & $\begin{array}{l}\text { Bi-jaw surgery vs single jaw } \\
\text { surgery } \\
\text { Mandibular surgery }> \\
\text { Pre-existing or chronic pain }\end{array}$ \\
\hline $\begin{array}{l}\text { Preoperative use of opioids / } \\
\text { neuropathic analgesics [98] }\end{array}$ & Oncological surgery \\
\hline & $\begin{array}{l}\text { Emergency procedures } \\
{[101]}\end{array}$ \\
\hline
\end{tabular}

\subsubsection{Postoperative Pain Management}

Postoperative analgesia has traditionally been achieved by prescribing analgesics with instructions to take as and when necessary. Experience with this approach was that many patients would not take the medication until the onset of significant pain. This practice earned the maxillofacial surgery the reputation of being an extremely painful one. The truth is that the postoperative pain management can be successfully achieved by carefully planning the delivery of the pain control measures at the appropriate time in the peri- and postoperative periods.

Pain perception is a subjective feeling, which is amplified by many factors and identification of the patients who are "at risk" for the development of severe postoperative pain would help in charting out an individualized management plan [97] (Table 10.16).

Identifying predictors of postoperative pain in patients before surgery, educating patients at the preoperative visit regarding the expected pain, and presenting the postoperative pain management plan will prepare patients better and relieve some of their anxiety regarding the procedure. An increased awareness of the importance of the psychological factors will allow more effective pain management.

\subsubsection{Pharmacological Management of Postoperative Pain}

The postoperative pain management is usually done with opioids and nonsteroidal class of anti-inflammatory drugs.

\subsubsection{Opioids}

Opioids have been in use for moderate-to-severe pain relief for a long period. References to opium poppy can be found in Sumerian and Egyptian culture, as back as 300 BC. The opium poppy, Papaver somniferum, gives rise to more than
Table 10.17 Opioid analgesics

\begin{tabular}{|l|l}
\hline Drug name & Dose \\
\hline Codeine & $15-60 \mathrm{mg}$ orally q4-6h \\
\hline Hydrocodone & $5-10 \mathrm{mg}$ orally q3h \\
\hline Oxycodone & $5-7.5 \mathrm{mg}$ orally q6h \\
\hline Meperidine & $50-150 \mathrm{mg}$ orally q3-4h \\
\hline Pentazocine & $50 \mathrm{mg}$ orally q3-4h \\
\hline Tramadol & $50-100 \mathrm{mg} \mathrm{q} 4-6 \mathrm{~h}, \mathrm{max} 400 \mathrm{mg} /$ day
\end{tabular}

Table 10.18 Side effects of opioid analgesics

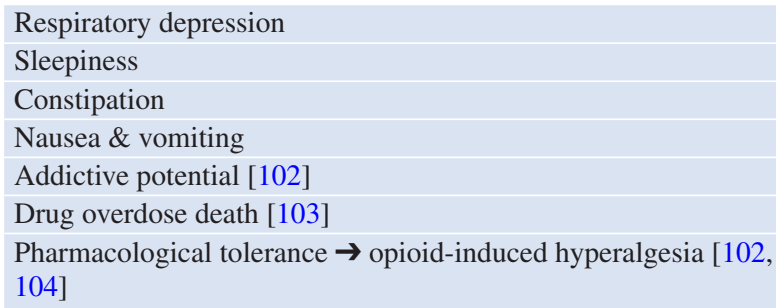

20 different alkaloids [100]—morphine and codeine being the main ones (Table 10.17).

Opiate alkaloids exert their action by acting on the opioid receptors- $\mu, \kappa, \delta$ (mu, kappa, and delta), which otherwise provide sites for activation of endogenously released opioid substances - beta-endorphins, enkephalins, and dynorphin compounds, which produce endogenous central analgesia. Opiate agonists produce analgesia by inhibiting excitatory neurotransmission of substance $\mathrm{P}$, acetylcholine, noradrenaline, and dopamine.

Unfortunately, opioid use, even when prescribed for short periods, comes with certain risks (Table 10.18).

For these reasons, most opioid agents used in outpatient postsurgical pain management are formulated in combination with non-narcotic analgesics [104]. This formulation potentiates the analgesic effects of the individual agents within the formulation while minimizing the side effects of pure opioid administration [105].

\subsubsection{Tramadol}

Tramadol, a synthetic substance with both opioid and nonopioid properties, is structurally related to codeine. It exhibits antidepressant and anxiolytic-like effects, in addition to analgesic action. It is considered safe for long-term use unlike NSAIDs with their potential for impairment of renal function and gastrointestinal complications, and with respect to other opioid medications for its low addiction rate and favorable safety profile. The most common adverse effect of tramadol is nausea and vomiting, especially with oral administration. Tramadol is contraindicated in patients with poorly controlled epilepsy because of its excitatory serotonergic effects. It is available either 
as a single drug or in combination with acetaminophen. Submucosal injection of tramadol at the extracted site of third molars has been proven effective in reducing the postoperative pain [106]. It suffers no side effects of systemic administration.

\subsubsection{Nonsteroidal Anti-Inflammatory Drugs (NSAIDs)}

NSAIDs have been in use for the treatment of pain, fever, and inflammation since late 1800 [107]. The antiinflammatory and analgesic properties of these drugs without the side effects and the addictive potential of opioids have made this class of drugs the first choice in ambulatory dentoalveolar procedures (Table 10.19).

They are a group of chemically heterogeneous compounds with several similar pharmacologic actions like antiinflammatory, antipyretic, analgesic, and antiplatelet actions. They primarily act at the site of tissue injury by inhibiting the synthesis of prostaglandins within the endoperoxide pathway (Fig. 10.1).

Table 10.19 Nonsteroidal anti-inflammatory drugs

\begin{tabular}{|c|c|c|}
\hline Drug name & Action & Analgesic Dose \\
\hline $\begin{array}{l}\text { Salicylic acid } \\
\text { derivative-Acetyl } \\
\text { salicylic acid }\end{array}$ & $\begin{array}{l}\text { Analgesic, anti- } \\
\text { inflammatory, } \\
\text { antiplatelet, } \\
\text { antipyretic- } \\
\text { Nonselective cox } \\
\text { inhibitor }\end{array}$ & $\begin{array}{l}325-650 \mathrm{mg} \text { orally } \\
\text { q4h / } 1000 \mathrm{mg} \text { orally } \\
\text { q6h. }\end{array}$ \\
\hline $\begin{array}{l}\text { Propionic acid } \\
\text { derivative- } \\
\text { Ibuprofen }\end{array}$ & $\begin{array}{l}\text { Analgesic, anti- } \\
\text { inflammatory, } \\
\text { antipyretic- } \\
\text { Nonselective cox } \\
\text { inhibitor }\end{array}$ & $\begin{array}{l}400-600 \mathrm{mg} \text { orally } \\
\mathrm{q} 4-6 \mathrm{~h}\end{array}$ \\
\hline $\begin{array}{l}\text { Propionic acid } \\
\text { derivative- } \\
\text { Naproxen }\end{array}$ & $\begin{array}{l}\text { Analgesic, antipyretic- } \\
\text { Nonselective cox } \\
\text { inhibitor }\end{array}$ & $\begin{array}{l}550 \mathrm{mg} \text { orally } \\
\text { initially, then } 275 \mathrm{mg} \\
\text { orally q6-8h }\end{array}$ \\
\hline $\begin{array}{l}\text { Acetic acid } \\
\text { derivative- } \\
\text { Keterolac }\end{array}$ & $\begin{array}{l}\text { Analgesic, antipyretic- } \\
\text { Nonselective cox } \\
\text { inhibitor }\end{array}$ & $\begin{array}{l}30 \mathrm{mg} \text { IV or } 60 \mathrm{mg} \\
\text { IM q6h / } 20 \mathrm{mg} \\
\text { orally initially, then } \\
10 \mathrm{mg} \text { orally q4-6h }\end{array}$ \\
\hline $\begin{array}{l}\text { Acetic acid } \\
\text { derivative- } \\
\text { Diclofenac }\end{array}$ & $\begin{array}{l}\text { Analgesic, anti- } \\
\text { inflammatory- } \\
\text { Nonselective cox } \\
\text { inhibitor }\end{array}$ & $\begin{array}{l}50-75 \mathrm{mg} \text { orally/IV } \\
\text { q12h }\end{array}$ \\
\hline $\begin{array}{l}\text { Oxicams- } \\
\text { Piroxicam }\end{array}$ & $\begin{array}{l}\text { Analgesic, anti- } \\
\text { inflammatory- } \\
\text { Nonselective cox } \\
\text { inhibitor }\end{array}$ & $\begin{array}{l}10-20 \mathrm{mg} \text { orally } \mathrm{q} \\
12 \mathrm{~h}\end{array}$ \\
\hline $\begin{array}{l}\mathrm{N} \text { - phenyl- } \\
\text { anthranilates- } \\
\text { Mefenamic acid }\end{array}$ & $\begin{array}{l}\text { Analgesic, anti- } \\
\text { inflammatory- } \\
\text { Nonselective cox } \\
\text { inhibitor }\end{array}$ & $\begin{array}{l}500 \mathrm{mg} \text { load, then } \\
250 \mathrm{mg} \text { q6h orally }\end{array}$ \\
\hline Celecoxib & Cox 2 inhibitor & $\begin{array}{l}200 \mathrm{mg} \text { orally } \\
\mathrm{q} 24 \mathrm{~h} / 100 \mathrm{mg} \text { orally } \\
\mathrm{q} 12 \mathrm{~h}\end{array}$ \\
\hline
\end{tabular}

Historically, majority of the NSAIDs were nonselective COX inhibitors with side effects related to the blockade of cytoprotective prostanoids - gastric irritation, increased bleeding time, and renal impairment. Over the past few years, selective COX2 inhibitors have been developed, which block the COX-2-mediated prostaglandins while maintaining the physiologically beneficial effects of the COX-1 isoenzyme [108].

Overall, NSAIDs are safe drugs to be used in the management of acute/postoperative pain. Parenteral use of NSAIDs has shown to be more effective in pain control [109]. About $60 \%$ of the patients would respond to the first NSAID, and the rest would show benefit with another NSAID. Ibuprofen is a widely used NSAID, with proven efficacy [110]. About $5 \%$ people experience "aspirin-sensitive asthma," probably due to the inhibition of Cox enzyme. Because of the probable mechanism of inducing asthma, it is felt that selective Cox 2 inhibitors may not cause asthmatic attacks [111].

\subsubsection{Paracetamol}

Paracetamol or acetaminophen is a widely available analgesic with an antipyretic action. It acts by inhibition of the COX-3 isoenzyme, reducing the production of prostanoids in the central nervous system. This central inhibition explains the antipyretic action of paracetamol. Paracetamol shows an excellent result in relieving mild-to-moderate pain relief and fever [112]. When used in combination with other analgesics, it shows superior analgesic power, thereby reducing the dose of opioids required [96].

\subsubsection{Guidelines to the Use of Analgesics}

Since there is no definitive evidence or clear algorithms, the selection of NSAIDs, to a large extent, depends on clinical experience and side effects. Patient convenience and cost also play a minor role in the selection of analgesics.

Laskarides (2016), in his review on control of dental pain, puts forward his observations (Table 10.20) [113].

\subsubsection{Analgesic Ladder}

WHO initially described the concept of "pain ladder" in their guidelines for the use of drugs for the management of cancer pain [114]. The concept has been now accepted in the management of all types of pain [104]. The concept is based on the use of first line of drugs for the mild-to-moderate pain and then climb the ladder to more potent drugs if pain still persists. Please see chapter on postoperative care, to view the analgesic ladder. 
Table 10.20 Key points in using analgesics

1 Care to administer correct dose of opioids [100-103]

2 Opioids + NSAIDs - centrally acting - + peripherally acting analgesia $\rightarrow$ moderate-to-severe pain relief

3 Tramadol—opioid \& nonopioid properties—safe for long-term use [106].

4 Ibuprofen-excellent analgesia, transition drug to wean off form opioids [110, 113].

5 Use NSAIDs with caution-cardiovascular conditions \& gastric irritation.

6 Paracetamol, tramadol, \& short-acting opioids-drugs of choice [113].

7 NSAIDs drug interactions -

Sulfonyl urea \& other hypoglycemic agents

Oral anticoagulants

Phenytoin

Sulfonamides

8 Paracetamol + NSAIDs-superior analgesic power [89, 112].

9 Maximum daily dose of paracetamol $4 \mathrm{~g}$ decides the dose of combination therapy [113].

\subsubsection{Preventive/Protective/Multimodal Analgesia}

Pain is multifactorial in origin and multiple techniques and drugs may be required to achieve control over it. The simultaneous use of different classes of analgesics and techniques has been called preventive, protective, or multimodal analgesia [115]. This approach uses a combination of drugs that act at different sites of action on the nervous system by different mechanisms to prevent peripheral and central sensitization of pain. It results in additive analgesia, but with lowered side effects than the single agents when used alone. Intraoperative local anesthesia followed by a range of analgesic drugs have been found to be effective in controlling the pain in day cases and reduces the need for opioid analgesics [116].

The complex surgeries involving multiple surgical sites as in head and neck oncological cases and craniofacial surgeries would gain hugely from the administration of multimodal analgesia. Multimodal analgesia can be successfully achieved by combining the currently available analgesic modalities (Table 10.21).

\subsubsection{Patient-Controlled Analgesia (PCA)}

Patient-controlled analgesics are intravenous agents, delivered through a microprocessor-controlled infusion pump, in which a predetermined dose can be delivered by the press of a button, and a lockout time can be set, so that patient cannot overdose himself [119]. PCA is usually used in patients who are distressed at the thought of postoperative pain. Fentanyl, morphine, \& combinations are the usually used medications. Though PCA was initially thought to reduce the patient pain perception, thereby reducing the length of stay (LOS), studies have failed to show any statistically significant difference
Table 10.21 The analgesics and adjuncts that can be used in multimodal analgesia [117]

\begin{tabular}{|c|c|c|}
\hline Drugs & Examples & Mechanism of action \\
\hline A. Opioids [102]. & $\begin{array}{l}\text { Codeine, } \\
\text { Hydrocodone } \\
\text { Tramadol }\end{array}$ & $\begin{array}{l}\text { Inhibits excitatory } \\
\text { neurotransmission of } \\
\text { substance P, } \\
\text { acetylcholine, } \\
\text { noradrenaline, \& } \\
\text { dopamine. }\end{array}$ \\
\hline $\begin{array}{l}\text { B. Local anesthesia } \\
{[86,118]} \\
\text { techniques. }\end{array}$ & $\begin{array}{l}\text { Bupivacaine, } \\
\text { levobupivacaine \& } \\
\text { ropivacaine-nerve } \\
\text { blocks \& infiltration }\end{array}$ & $\begin{array}{l}\text { Blocks the pain } \\
\text { transmission }\end{array}$ \\
\hline $\begin{array}{l}\text { C. Acetaminophen } \\
\text { [112]. }\end{array}$ & Weak analgesic & $\begin{array}{l}\text { IV administration } \\
\text { raises the plasma \& } \\
\text { CSF concentration } \\
\text { rapidly to achieve } \\
\text { adequate analgesia }\end{array}$ \\
\hline $\begin{array}{l}\text { D. Nonsteroidal } \\
\text { anti-inflammatory } \\
\text { drugs (NSAIDs) } \\
{[108,110] .}\end{array}$ & $\begin{array}{l}\text { Ibuprofen, } \\
\text { Diclofenac, } \\
\text { Mefenamic acid, } \\
\text { nasal spray of } \\
\text { ketorolac }\end{array}$ & $\begin{array}{l}\text { Blocks arachidonic } \\
\text { acid metabolism }\end{array}$ \\
\hline $\begin{array}{l}\text { E. Cyclooxygenase } \\
\text { (COX)-2-specific } \\
\text { inhibitors [108]. }\end{array}$ & Celecoxib & Cox 2 inhibitor \\
\hline \multicolumn{3}{|l|}{ F. Adjuncts. } \\
\hline 1. Steroids [80]. & $\begin{array}{l}\text { Dexamethasone, } \\
\text { hydrocortisone }\end{array}$ & $\begin{array}{l}\text { Blocks lipoxygenase \& } \\
\text { cox pathways }\end{array}$ \\
\hline $\begin{array}{l}\text { 2. N-methyl-d- } \\
\text { aspartate } \\
\text { (NMDA). } \\
\text { Antagonists } \\
{[97,115,117]}\end{array}$ & Ketamine & $\begin{array}{l}\text { Effects on central } \\
\text { sensitization \& neural } \\
\text { modulation }\end{array}$ \\
\hline $\begin{array}{l}\text { 3. Alpha }-2 \\
\text { agonists }[97, \\
115,117] \text {. }\end{array}$ & $\begin{array}{l}\text { Clonidine, } \\
\text { Dexmedetomidine }\end{array}$ & $\begin{array}{l}\text { Sedative and analgesia- } \\
\text { sparing effects via } \\
\text { central actions in the } \\
\text { locus ceruleus and in } \\
\text { the dorsal horn of the } \\
\text { spinal cord, } \\
\text { respectively }\end{array}$ \\
\hline $\begin{array}{l}\text { 4. Anticonvulsants } \\
{[97,115,117] \text {. }}\end{array}$ & $\begin{array}{l}\text { Gabapentin, } \\
\text { pregabalin }\end{array}$ & $\begin{array}{l}\text { Inhibits central } \\
\text { sensitization through } \\
\text { presynaptic or } \\
\text { postsynaptic inhibition } \\
\text { of calcium influx, } \\
\text { which inhibits the } \\
\text { release of } \\
\text { neurotransmitters }\end{array}$ \\
\hline
\end{tabular}

in the pain score and the LOS between the PCA group \& non-PCA group of patients after orthognathic surgery [119, 120]. This could be attributed to the fact that the subjects in the PCA group were predominantly bijaw surgery patients for whom the surgical time was longer and the surgical procedure resulted in more tissue injury. But from patient's perspective, PCA is the preferred method, as they feel in charge of their own pain control [121]. 


\subsection{Corticosteroids in Maxillofacial Surgery}

When tissue damage occurs as a result of injury, body's natural defense mechanism is inflammation and body tries to heal. But overt inflammation results in pain, edema, and limitation of movement, trismus. These symptoms may not be evident immediately, but peak after the second day, returning to normal by seventh postoperative day [122]. Corticosteroids suppress the inflammation (Fig. 10.1) by interfering with the capillary dialatation, fluid transduation, fibrin deposition, leukocyte migration, and phagocytosis. Under normal nonstressful conditions, the body produces approximately 15 to $30 \mathrm{mg}$ of hydrocortisone/cortisol per day. During stressful situations, $300 \mathrm{mg}$ of hydrocortisone per day can be produced. Generally speaking, to suppress inflammation, the dose of exogenous corticosteroids must exceed the normal physiological amounts of hydrocortisone released [123].

The first reported clinical use of the anti-inflammatory properties of corticosteroids was in the treatment of rheumatoid artritis [124], following which its efficacy was tried in maxillofacial surgical procedures. The use of steroids and their effectiveness have been extensively studied in the third molar surgeries - the most commonly performed maxillofacial surgical procedure [125]. Markiewicz et al. noted that postoperative findings of swelling, trismus, and pain were significantly lower in the group who received corticosteroids, than in the control group in the immediate postoperative period (1-3 days) [126].

The use of dexamethasone and methyl prednisolone, in controlling the postoperative sequel of third molar surgery when these drugs are administered via parenteral [127], oral
[128] submucosal $[129,130]$ and topical [131] routes, has been reported.

Studies have evaluated different formulations, dosages, and routes and sites of administration of corticosteroids, without any consensus. (Table 10.22).

Dexamethasone has a longer duration of action than methylprednisolone and is considered more potent. Intralesional/intramasseteric injection of dexamethasone is found to be better than the intravenous or parenteral administration in controlling postoperative edema $\&$ trismus and has an additional benefit of being given through an alreadyanesthetized area $[130,132]$.

Almeida et al. (2019) [133] failed to note any benefit of submucosal injection of steroid at the local site. Authors gave the reason for this as the displacement of the medicine from the local site when mucoperiosteal flap is reflected to expose the tooth. Similarly, the merits of intravenous administration of steroids perioperatively in major surgeries have been questioned by a group of authors [134]. Kainulainen et al. [134] reported infectious complications-pneumonia, gastrostomy site infections, \& surgical site infections in oncological cases.

Though the reduction of edema brings about some reduction in discomfort, steroids alone do not have a clinically significant analgesic effect $[130,135]$ This has been attributed to the inability of the steroids to block the production of neurotransmitters by the injured tissues and central sensitization to pain. The combination of dexamethasone with tramadol or diclofenac sodium has been proven more effective in controlling postoperative pain and trismus, as opposed to corticosteroids alone [136]. Alexander \& Throndson [127] summarized few salient points with regard to usage of steroids, based on their review (Table 10.23).

Table 10.22 Commonly used steroids with their anti-inflammatory potency\& equivalent dose and commonly used doses [1]

\begin{tabular}{|c|c|c|c|c|}
\hline Drug & Duration of action & Anti-inflammatory potency & Equivalent dose & Dose \\
\hline Dexamethasone & Long acting & 25 & $0.75 \mathrm{mg}$ & $0.5-5 \mathrm{mg} /$ day PO, 4-20 mg /day IV \\
\hline Betamethasone & Long acting & 25 & $0.75 \mathrm{mg}$ & $0.5-5 \mathrm{mg} /$ day $\mathrm{PO}, 4-20 \mathrm{mg} /$ day IV \\
\hline Prednisolone & Intermediate acting & 4 & $5 \mathrm{mg}$ & $\begin{array}{l}5-60 \mathrm{mg} / \text { day PO } \\
10-40 \mathrm{mg} / \text { day IM or IV }\end{array}$ \\
\hline Methyl prednisolone & Intermediate acting & 5 & $4 \mathrm{mg}$ & 4-32 mg /day PO \\
\hline Triamcinolone & Intermediate acting & 5 & $4 \mathrm{mg}$ & $\begin{array}{l}4-32 \mathrm{mg} / \text { day PO } \\
5-40 \mathrm{mg} \text { intra-articular }\end{array}$ \\
\hline Hydrocortisone & Short acting & 1 & $20 \mathrm{mg}$ & 100 mg IV/IM bolus \\
\hline
\end{tabular}


Table 10.23 Summary of corticosteroid use in maxillofacial surgery

1 Preoperative intralesional / parenteral administration of steroids to reduce the inflammation associated with surgery $[125,132]$.

2 No adrenal suppression with small doses [125]

3 Long-term use-adrenal suppression interference with immune system \& infection [126]

4 Usually tapering of dose is not required for short-term uses [137]

5 Contraindications [138]:

Active tuberculosis

Active viral / fungal infections

Active acne vulgaris

Primary glaucoma

Patients with psychoses

6 Use with care [138]:

Diverticulitis

Peptic ulcers

Cushing's syndrome

Renal insufficiency

Uncontrolled hypertension

Uncontrolled diabetes mellitus

Pregnancy \& lactation

Chronic infections

Myasthenia gravis

8 Exogenous steroid dose $>$ endogenous cortisol level [123, 138]

\subsection{Conclusion}

Maxillofacial surgical practice involves use of many therapeutics to facilitate the treatment or promote healing. A careful evaluation of these drugs or reported literature, a detailed knowledge about their side effects, interactions with other chemicals, and how any alterations in the patient's physiology enhance or suppress the mechanism of action of these drugs is needed before their use or prescription. It is always prudent to remember that no medicine is without side effects and the benefits of using them should be weighed against the risks involved.

\section{References}

1. Dandon RH, Brual LL. Goodman \& Gilman's manual of pharmacology and therapeutics. 2nd ed. New York: McGraw Hill Education; 2014.

2. Gaynes R. The discovery of penicillin - new insights after more than 75 years of clinical use. Emerg Infect Dis. 2017;23(5): 849-53.

3. Waksman SA. What is an antibiotic or antibiotic substance? Mycologia. 1947;39(5):565-9.

4. Salit IE. Diagnostic approaches to head and neck infections. Infect Dis Clin N Am. 1988;2:35-55.

5. Kuriyama T, Karasawa T, Nakagawa K, Saiki Y, Yamamoto E, Nakamura S. Bacteriologic features and antimicrobial susceptibil-

ity in isolates from orofacial odontogenic infections. Oral Surg Oral Med Oral Pathol Oral Radiol Endod. 2000;90:600-8.

6. Paterson SA, Curzon MEJ. The effect of amoxicillin versus penicillin $\mathrm{V}$ in the treatment of acutely abscessed primary teeth. $\mathrm{Br}$ Dent J. 1993;174:443-9.

7. Chang C, et al. Overview of penicillin allergy. Clinic Rev Allerg Immunol. 2012;43:84-97.

8. Raz R, Elchanan G, Colodner R, et al. Penicillin V twice daily vs four times daily in the treatment of streptococcal pharyngitis. Infect Dis Clin Pract. 1995;4:50-4.

9. Martin MP, Longman LP, Hill JB, et al. Acute dento alveolar infections: an investigation of the duration of antibiotic therapy. Br Dent J. 1997;183:135-7.

10. DePestel DD, et al. Cephalosporin use in treatment of patients with penicillin allergies. J Am Pharm Assoc. 2008;48:530-40.

11. Kelkar PS, Li JT. Cephalosporin allergy. N Engl J Med. 2001;345:804-9.

12. Burke JF. The effective period of preventative antibiotic action in experimental incisions and dermal lesions. Surgery. 1961;50:161-8.

13. Miles AA, Miles EM, Burke J. The value and duration of defense reaction of the skin to the primary lodgment of bacteria. Br J Exp Pathol. 1957;38:79-96.

14. Classen DC, Evans RS, Pestotnik SL, et al. The timing of prophylactic administration of antibiotics and risk of surgical-wound infection. N Engl J Med. 1992;326:281-6.

15. Pallasch TJ. Antibiotic prophylaxis: the clinical significance of its recent evolution. J Calif Dent Assoc. 1997;25(619-24):26-32.

16. Kamolratanakul P, Jansisyanont P. A review of antibiotic prophylaxis protocols in oral and maxillofacial surgery. J Oral Maxillofac Surg Med Pathol. 2018;30:395-404.

17. Garner JS. CDC guideline for prevention of surgical wound infections, 1985. Supersedes guideline for prevention of surgical wound infections published in 1982. (originally published in November 1985). Revised. Infect Control. 1986;7:193-200.

18. Peterson LJ. Antibiotic prophylaxis against wound infections in oral and maxillofacial surgery. J Oral Maxillofac Surg. 1990;48:617-620.

19. Tan SK, Lo J, Zwahlen RA. Perioperative antibiotic prophylaxis in orthognathic surgery: a systematic review and meta-analysis of clinical trials. Oral Surg Oral Med Oral Pathol Oral Radiol Endod. 2011;112:19-27.

20. Sancho-Puchades M, Herraez-Vilas JM, Berini-Aytes L, GayEscoda C. Antibiotic prophylaxis to prevent local infection in Oral surgery: use or abuse? Oral Med Oral Patol Oral Cir Bucal. 2009; 14:E28-33.

21. Lewis MAO, McGowan DA, Macfarlane TW. Short - course, high-dosage amoxicillin in the treatment of acute dento-alveolar abscess. Br Dent J. 1986;161:299-302.

22. Lodi G, Figini L, Sardella A, Carrassi A, Del Fabbro M, Furness S. Antibiotics to prevent complications following tooth extractions. Cochrane Database Syst Rev. 2012;11:CD003811.

23. Figueiredo R, Valmaseda-Castellon E, Formoso-Senande MF, Berini-Aytes L, GayEscoda C. Delayed-onset infections after impacted lower third molar extraction: involved bacteria and sensitivity profiles to commonly used antibiotics. Oral Surg Oral Med Oral Pathol Oral Radiol Endod. 2012;144:43-8.

24. Sekhar CH, Narayanan V, Baig MF. Role of antimicrobials in third molar surgery: prospective, double blind, randomized, placebo-controlled clinical study. Br J Oral Maxillofac Surg. 2001;39:134-7. 
25. Adde CA, Soares MS, Romano MM, et al. Clinical and surgical evaluation of the indication of postoperative antibiotic prescription in third molar surgery. Oral Surg Oral Med Oral Pathol Oral Radiol. 2012;114(5 Suppl):S26-31.

26. Lacasa JM, Jimenez JA, Ferras V, Bossom M, Sola-Morales O, Garcia-Rey C, et al. Prophylaxis versus pre-emptive treatment for infective and inflammatory complications of surgical third molar removal: a randomized, double-blind, placebo-controlled, clinical trial with sustained release amoxicillin/clavulanic acid (1000/ $62.5 \mathrm{mg}$ ). Int J Oral Maxillofac Surg. 2007;36:321-7.

27. Pasupathy S, Alexander M. Antibiotic prophylaxis in third molar surgery. J Craniofac Surg. 2011;22:551-3.

28. Menon RK, Gopinath D, Li KY, et al. Does the use of amoxicillin/amoxicillin-clavulanic acid in third molar surgery reduce the risk of postoperative infection? A systematic review with meta-analysis. Int J Oral Maxillofac Surg. 2018;48(2): 263-73.

29. Poeschl PW, Eckel D, Poeschl E. Postoperative prophylactic antibiotic treatment in third molar surgery-a necessity? J Oral Maxillofac Surg. 2004;62:3-8. Discussion 9

30. Larsen PE. The effect of chlorhexidine rinse on the incidence of alveolar osteitis following the surgical removal of impacted mandibular third molars. J Oral Maxillofac Surg. 1991;49:932-7.

31. Lyall JB. Third molar surgery: the effect of primary closure, wound dressing and metroniadazole on postoperative recovery. $\mathrm{J}$ R Army Med Corps. 1991;137:100-3.

32. Ren Y-F, Malmstrom HS. Effectiveness of antibiotic prophylaxis in third molar surgery: a meta-analysis of randomized controlled clinical trials. J Oral Maxillofac Surg. 2007;65(10):1909-21.

33. Resnik RR, Misch C. Prophylactic antibiotic regimens in oral implantology: rationale and protocol. Implant Dent. 2008; 17:142-50.

34. Rasmusson L, Roos J, Bystedt H. A 10-year follow-up study of titanium dioxide-blasted implants. Clin Implant Dent Relat Res. 2005;7(1):36-42.

35. Friberg B. Sterile operating conditions for the placement of intraoral implants. J Oral Maxillofac Surg. 1996;54:1334-6.

36. Esposito M, Coulthard P, Oliver R, Thomsen P, Worthington HV. Antibiotics to prevent complications following dental implant treatment. Cochrane Database Syst Rev. 2003:CD004152.

37. Hossein K, Dahlin C, Bengt A. Influence of different prophylactic antibiotic regimens on implant survival rate: a retrospective clinical study. Clin Impl Dent Rel Res. 2005;7(1):32-5.

38. Davis CM, Gregoire CE, Steeves TW, et al. Prevalence of surgical site infections following orthognathic surgery: a retrospective cohort analysis. J Oral Maxillofac Surg. 2016;74:1199-206.

39. Chow LK, Singh B, Chiu WK, Samman N. Prevalence of postoperative complications after orthognathic surgery: a 15-year review. J Oral Maxillofac Surg. 2007;65:984-92.

40. Horan TC, Gaynes RP, Martone WJ, Jarvis WR, Emori G. CDC definitions of nosocomial surgical site infections, 1992: a modification of CDC definitions of surgical wound infections. Infect Control Hosp Epidemiol. 1992;13(10):606-8.

41. Danda AK, Ravi PE. Ectiveness of postoperative antibiotics in orthognathic surgery: a meta-analysis. J Oral Maxillofac Surg. 2011;69:2650-6.

42. Posnick JC, Choi E, Chavda A. Surgical site infections following bimaxillary orthognathic, osseous genioplasty, and intranasal surgery: a retrospective cohort study. J Oral Maxillofac Surg. 2017;75:584-95.

43. Danda AK, Wahab A, Narayanan V, Siddareddi A. Single-dose versus single-day antibiotic prophylaxis for orthognathic surgery: a prospective, randomized, double-blind clinical study. J Oral Maxillofac Surg. 2010;68:344-6.

44. Brignardello-Petersen R, Carrasco-Labra A, Araya I, Yanine N, Cordova Jara L, Villanueva J. Antibiotic prophylaxis for prevent- ing infectious complications in orthognathic surgery. Cochrane Database Syst Rev. 2015;1:CD010266.

45. Mangram AJ, Horan TC, Pearson ML, et al. Guideline for prevention of surgical site infection, 1999. Centers for Disease Control and Prevention (CDC) hospital infection control practices advisory committee. Am J Infect Control. 1999;27:97-132.

46. Peel TN, Buising KL, Choong PF. Prosthetic joint infection: challenges of diagnosis and treatment. ANZ J Surg. 2011;81:32-9.

47. Fridrich KL, Partnoy BE, Zeitler DL. Prospective analysis of antibiotic prophylaxis for orthognathic surgery. Int J Adult Orthodontics Ortho Surg. 1994;9(2):129-31.

48. Laskin DM. The use of prophylactic antibiotics for the prevention of postoperative infections. Oral Maxillofac Surg Clin North Am. 2003;15:155-60.

49. Abubaker O, Rollert MK. Postoperative antibiotic prophylaxis in mandibular fractures: a preliminary randomized, double-blind, and placebo-controlled clinical study. J Oral Maxillofac Surg. 2001;59:1415-9.

50. Haug RH, Assael LA. Infection in the maxillofacial trauma patient. In: Topazian RG, Goldberg MH, Hupp JR, editors. Oral and Maxillofacial Infections. Ed 4. Philadelphia: PA, Saunders; 2002. p. 359-80.

51. Andreasen JO, Jensen SS, Schwartz O, Hillerup Y. A systematic review of prophylactic antibiotics in the surgical treatment of maxillofacial fractures. J Oral Maxillofac Surg. 2006;64:1664-8.

52. Dillon JK, Christensen B, McDonald T, et al. The financial burden of mandibular trauma. J Oral Maxillofac Surg. 2012;70:2124-34.

53. Shridharani SM, Berli J, Manson PN, et al. The role of postoperative antibiotics in mandible fractures: a systematic review of the literature. Ann Plast Surg. 2015;75:353-7.

54. Gaal A, Patel Y, Smiley N, et al. Limiting antibiotics when managing mandible fractures may not increase infection risk. J Oral Maxillofac Surg. 2016;74:2008-18.

55. Baliga SD, Bose A, Jain S. The evaluation of efficacy of postoperative antibiotics in the open reduction of the zygomatic and mandibular fracture: a prospective trial. J Maxillofac Oral Surg. 2014;13:165-75.

56. Miles BA, Potter JK, Ellis E. The efficacy of postoperative antibiotic regimens in the open treatment of mandibular fractures: a prospective randomized trial. J Oral Maxillofac Surg. 2006;64:576-82.

57. Goodson WH III, Hunt TK. Wound healing and the diabetic patient. Surg Gynecol Obstet. 1979;149:600-8.

58. Zoeller GN, Kadis B. The diabetic dental patient. Gen Dent. 1981;29:58-61.

59. Rahimi-Nedjat RK, Sagheb K, Pabst A, et al. Diabetes and hyperglycemia as risk factors for postoperative outcome in maxillofacial surgery. J Surg Res. 2017;217:170-6.

60. Ramaraj PN, Cariappa KM. Is there a need for antibiotic prophylaxis after routine dental extraction in diabetic patients? Br J Oral Maxillofac Surg. 2006;44:421.

61. Lee DH, Kim SY, Nam SY, Choi SH, Choi JW, Roh JL. Risk factors of surgical site infection in patients undergoing major oncological surgery for head and neck cancer. Oral Oncol. 2011;47:528-31.

62. Bartella A, Kamal M, Teichmann J, et al. Prospective comparison of perioperative antibiotic management protocols in oncological head and neck surgery. J Cran-Max-Fac Surg. 2017;45:1078-82.

63. Zhang Y, Dong J, Qiao Y, He J, Wang T, Ma S. Efficacy and safety profile of antibiotic prophylaxis usage in clean and cleancontaminated plastic and reconstructive surgery: a meta-analysis of randomized controlled trials. Ann Plast Surg. 2014;72:121-30.

64. Ariyan S, Martin J, Lal A, Cheng D, Borah GL, Chung KC, et al. Antibiotic prophylaxis for preventing surgical-site infection in plastic surgery: an evidence-based consensus conference statement from the American Association of Plastic Surgeons. Plast Reconstr Surg. 2015;135:1723-39. 
65. Mercer NSG. The use of preoperative swabs in cleft lip and palate repair. Br J Plast Snrg. 2002;55:176-7.

66. Moss ALH. The use of preoperative swabs in cleft lip and palate repair. Br J Plast Surg. 2002;55:533-4.

67. Chuo CB, Timmons MJ. The bacteriology of children before primary cleft lip and palate surgery. The Cleft Palat-Craniofac J. 2005;42(3):272-6.

68. Rennie AL, Treharne LJ, Richard B. Throat swabs taken on the operating table prior to cleft palate repair and their relevance to outcome: a prospective study. Cleft Palate Craniofac J. 2009 May;46(3):275-9.

69. Aznar ML, Schönmeyr B, Echaniz G, et al. Role of postoperative antimicrobials in cleft palate surgery. Plast Recon Surg. 2015;136(1):59e-66e.

70. Douglas LR, Douglass JB, Sieck JO, Smith PJ. Oral management of the patient with end-stage liver disease and the liver transplant patient. Oral Surg Oral Med Oral Pathol Oral Radiol Endod. 1998;86:55-64.

71. Guggenheimer J, Mayher D, Eghtesad B. A survey of dental care protocols among US organ transplant centers. Clin Transpl. $2005 ; 19: 15-8$

72. Lewis T, Grant RT. Observations relating to subacute infective endocarditis. BrHeart J. 1923;10:21-77.

73. Jones TD, Baumgartner L, Bellows MT, et al. Prevention of rheumatic fever and bacterial endocarditis through control of streptococcal infections. Circulation. 1955;11:317-20.

74. Wilson W, Taubert KA, Gewitz M, et al. American Heart Association. Prevention of infective endocarditis: guidelines from the American Heart Association: a guideline from the American Heart Association rheumatic fever, endocarditis and Kawasaki disease committee, council on cardiovascular disease in the young, and the council on clinical cardiology, council on cardiovascular surgery and anesthesia, and the quality of care and outcomes research interdisciplinary working group. JADA. 2008;139(suppl):3S-24S.

75. Gould FK, Elliott TSJ, Foweraker J, et al. Guidelines for the prevention of endocarditis: report of the working party of the British society for antimicrobial chemotherapy. J Antimicrob Chemother 2006;57:1035-42.

76. Prophylaxis against infective endocarditis. National institute for health and care excellence. 2008.

77. Habib G, Hoen B, Tornos P, et al. Guidelines on the prevention, diagnosis, and treatment of infective endocarditis (new version 2009): the task force on the prevention, diagnosis, and treatment of infective endocarditis of the European society of cardiology (ESC). Endorsed by the European society of clinical microbiology and infectious diseases (ESCMID) and the international society of chemotherapy (ISC) for infection and cancer. Eur Heart J. 2009;30:2369-413.

78. Pasquali SK, He X, Mohamad Z, et al. Trends in endocarditis hospitalizations at US children's hospitals: impact of the 2007 American Heart Association antibiotic prophylaxis guidelines. Am Heart J. 2012;163:894-9.

79. Sakai Bizmark R, Chang R-KR, Tsugawa Y, et al. Impact of AHA's 2007 guideline change on incidence of infective endocarditis in infants and children. Am Heart J. 2017;189:110-9.

80. Pain terms: a list with definitions and notes on usage. Recommended by the IASP Subcommittee on taxonomy. Pain. 1979;6:249-52.

81. Feizerfan A, Sheh G. Transition from acute to chronic pain. Contin Educ Anaesth Crit Care Pain. 2015;15:98-102.

82. Luo Y, Svensson P, Jensen JD, et al. Quantitative sensory testing in patients with or without ongoing pain one year after orthognathic surgery. J Oral Facial Pain Headache. 2014;28:306-16.

83. Desjardins P. Patient pain and anxiety: the medical and psychologic challenges facing oral and maxillofacial surgery. J Oral Maxillofac Surg. 2000;58(2):1-3.
84. Pedersen A. Interrelation of complaints after removal of impacted mandibular third molars. Int J Oral Surg. 1985;14:241-4.

85. Crane M, Green P, Gordon N. Pharmacology of opioid and non-opioid analgesics. Oral Maxillofacial Surg Clin N Am. 2001;13:1-13

86. Coulthard P, Bailey E, Patel N, Coulthard MB. Pain pathways and pre-emptive and protective analgesia for oral surgery. Oral Surg. 2013;7(2):74-80.

87. Woolf CJ, Chong MS. Preemptive analgesia treating postoperative pain by preventing the establishment of central sensitization. Anesth Analg. 1993;77:362-79.

88. Woolf CJ. Evidence for a central component of postinjury pain hypersensitivity. Nature. 1983;306:686-8.

89. Viswanath A, Oreadi D, Finkelman M, Klein G, Papageorge M. Does pre-Emptive Administration of Intravenous Ibuprofen (Caldolor) or intravenous acetaminophen(Ofirmev) reduce postoperative pain and subsequent narcotic consumption after third molar surgery? J Oral Maxillofac Surg. 2019;77(2):262-70.

90. Hutchison GL, Crofts SL, Gray IG. Preoperative piroxicam for postoperative analgesia in dental surgery. $\mathrm{Br} \mathrm{J}$ Anaesth. 1990;65:500-3.

91. Ong KS, Seymour RA, Chen FG, Ho VC. Preoperative ketorolac has a preemptive effect for postoperative third molar surgical pain. Int J Oral Maxillofac Surg. 2004;33:771-6.

92. Aoki T, Yamaguchi H, Naito H, Shiiki K, Izawa K, Ota Y, Sakamoto H, Kaneko A. Premedication with cyclooxygenase-2 inhibitor meloxicam reduced postoperative pain in patients after oral surgery. Int J Oral Maxillofac Surg. 2006;35:613-7.

93. Desjardins PJ, Grossman EH, Kuss ME, Talwalker S, Dhadda S, Baum D, Hubbard RC. The injectable cyclooxygenase-2-specific inhibitor parecoxib sodium has analgesic efficacy when administered preoperatively. Anesth Analg. 2001;93:721-7.

94. Moore PA, Brar P, Smiga ER, Costello BJ. Preemptive rofecoxib and dexamethasone for prevention of pain and trismus following third molar surgery. Oral Surg Oral Med Oral Pathol Oral Radiol Endod. 2005;99:e1-7.

95. Møiniche S, Kehlet H, Dah JB. A qualitative and quantitative systematic review of preemptive analgesia for postoperative pain relief: the role of timing of analgesia. Anesthesiology. 2002;96:725-34

96. Aznar Arasa L, Harutunian K, Figuereido R, et al. Effect of preoperative ibuprofen on pain and swelling after lower third molar removal: a randomized controlled trial. Int J Oral Maxillofac Surg. 2012;41:1005-9.

97. Evans SW, McCahon RA. Management of postoperative pain in maxillofacial surgery. $\mathrm{Br} \mathrm{J}$ Oral Maxillofac Surg. 2019;57(1):4-11.

98. De Cosmo G, Congedo E, Lai C, et al. Preoperative psychologic and demographic predictors of pain perception and tramadol consumption using intravenous patient-controlled analgesia. Clin J Pain. 2008;24:399-405.

99. Coulthard P, Haywood D, Tai MA, Jackson-Leech D, Pleuvry BJ, Macfarlane TV. Treatment of postoperative pain in oral and maxillofacial surgery. Br J Oral Maxillofac Surg. 2000;38(6):588-92.

100. Mobini A, Mehra P, Chigurupathy R. Postoperative pain and opioid analgesic requirements after orthognathic surgery. J Oral Maxillofac Surg. 2018;76:2285-95.

101. Moore PA, Hersch EV. Analgesic therapy in dentistry - from a letter to the editor to an evidence-base review. Dent Clin N Am. 2019;63:35-44.

102. Fletcher MC, Spera JF. Management of acute postoperative pain after oral surgery. Dent Clin N Am. 2012;56:95-111.

103. Rudd RA, Seth P, David F, Scholl L. Increases in drug and opioid involved overdose deaths-United States, 2010-2015. Morb Mortal Wkly Rep. 2016;65:1445-52. 
104. Patel N, Bailey E, Coulthard P. Opioids for pain after oral surgery. Oral Surg. 2013;7(4):196-202.

105. Moore RA, Derry S, McQuay HJ, Wiffen PJ. Single dose oral analgesics for acute postoperative pain in adults. Cochrane Database Syst Rev. 2011;9:CD008659.

106. Ceccheti MM, Negrato GV, de Melo Peres MP, et al. Analgesic and adjuvant anesthetic effect of submucosal tramadol after mandibular third molar surgery. Oral Surg Oral Med Oral Path Oral Radiol. 2014;117(3):e249-54.

107. Power I, Barratt S. Analgesic agents for the postoperative period: nonopioids. Surg Clin North Am. 1999;79:275-95.

108. Moore P, Hersh E. Celecoxib and rofecoxib, the role of COX-2 inhibitors in dental practice. J Am Dent Assoc. 2001;132: 451-6.

109. Seymour RA, Moore U, Hawkesford J, Coulthard P, JacksonLeech D, Thomas D, Hill M, Combs ML, Renton T, McGurk M. An investigation into the efficacy of intravenous diclofenac in post-operative dental pain. Eur J Clin Pharmacol. 2000 Sep;56(6-7):447-52.

110. Derry CJ, Derry S, Moore RA, McQuay HJ. Single dose oral ibuprofen for acute postoperative pain in adults. Cochrane Database Syst Rev. 2009;3:CD010210.

111. Gyllfors P, Bochenek G, Overholt J, et al. Biochemical and clinical evidence that aspirin intolerant asthmatic subjects tolerate the cyclooxygenase 2-selective analgesic drug celecoxib. J Allergy Clin Immunol. 2003;111:1116-21.

112. Weil K, Hooper L, Afzal Z, et al. Paracetamol for pain relief after surgical removal of wisdom teeth. Cochrane Database Syst Rev. 2007;3:CD004487.

113. Laskarides C. Update on analgesic medication for adult and pediatric dental patients. Dent Clin N Am. 2016;60:347-66.

114. World Health Organization. WHO Pain Ladder. 2013. Available from URL: http://www.who.int/cancer/palliative/painladder/en/

115. Buvanendran A, Kroin JS. Multimodal analgesia for controlling acute postoperative pain. Curr Opin Anaesthesiol. 2009;22:588-93.

116. Yong SL, Walsh T, Coulthard P. Protective analgesia for postoperative pain following third molar surgery [protocol]. Cochrane Database Syst Rev. 2010;9:CD008692.

117. Rosero EB, Joshi GP. Preemptive, preventive. Multimodal Analgesia Plast Recon Surg. 2014;134:85S-93S.

118. Rood JP, Coulthard P, Snowdon AT, Gennery BA. Safety and efficacy of levobupivacaine for postoperative pain relief after the surgical removal of impacted third molars: a comparison with lignocaine and adrenaline. Br J Oral Maxillofac Surg. 2002 Dec;40(6):491-6.

119. Chang FSC, Burrows A, Gebauer DP. Patient-controlled analgesia and length of hospital stay in orthognathic surgery: a randomized controlled trial. J Oral Maxillofac Surg. 2019;77:818-27.

120. Geha H, Nimeskern N, Beziat J. Patient-controlled analgesia in orthognathic surgery: evaluation of the relationship to anxiety and anxiolytics. Oral Surg Oral Med Oral Pathol Oral Radiol Endod. 2009;108:e33-6.

121. Hudcova J, McNicol ED, Quah CS, Lau J, Carr DB. Patient controlled opioid analgesia versus conventional opioid analgesia for postoperative pain. Cochrane Database Syst Rev. 2006;4:CD003348.

122. Peterson LJ. Postoperative patient management. In: Peterson LJ, Ellis E, Hupp JR, Tucker MR, editors. Contemporary oral and maxillofacial surgery. 3rd ed. St Louis: Mosby; 1998. p. 251.

123. Gilman AG, Rall TW, Nies AS, et al. The pharmacological basis of therapeutics (ed 8). New York, NY: Macmillan; 1990. p. 1436-52.

124. Axelrod L. Adrenal corticosteroids. In: Miller RR, Greenblatt, editors. Handbook of drug Therauv. New York. NY: Elsevier; 1979. p. 809-40.
125. Beirne OR, Hollander B. The effect of methylprednisolone on pain, trismus, and swelling after removal of third molar. Oral Surg Oral Med Oral Path. 1986;61:134-8.

126. Markiewicz MR, Brady MF, Ding EL, Dodson TB. Corticosteroids reduce postoperative morbidity after third molar surgery: a systematic review and meta-analysis. J Oral Maxillofac Surg. 2008;66(9):1881-94.

127. Alexander RE, Throndson RT. A review of perioperative corticosteroid use in dentoalveolar surgery. Oral Surg Oral Med Oral Pathol. 2000;90:406-15.

128. Montgomery MT, Hogg JP, Roberts DL, et al. The use of glucocorticosteroids to lessen the inflammatory sequelae following third molar surgery. J Oral Maxillofac Surg. 1990;48:179-87.

129. Pedersen A. Decadronphosphate in the relief of complaints after third molar surgery. Int J Oral Maxillofac Surg. 1985;14:235-40.

130. Grossi GB, Maiorana C, Garramone RA. Effect of submucosal injection of dexamethasone on postoperative discomfort after third molar surgery: a prospective study. J Oral Maxillofac Surg. 2007;65:2218-26.

131. Messer EJ, Keller JJ. The use of intraoral dexamethasone after extraction of mandibular third molar. Oral Surg Oral Med Oral Pathol. 1975;40:594-8.

132. Brucoli M, De Andreis M, Boffano BP, et al. Comparative assessment of dexamethasone administration routes for the management of postoperative symptoms following third molar surgery. $\mathrm{J}$ Stomatol Oral Maxillofac Surg. 2019.

133. de Almeida AC, Lemos CAA, de Moraes SLD, et al. Efficacy of corticosteroids versus placebo in impacted third molar surgery: systematic review and meta-analysis of randomized controlled trials. Int J Oral Maxillofac Surg. 2019;48:118-31.

134. Kainulainen S, Lassus P, Suominen AL, et al. More harm than benefit of perioperative dexamethasone on recovery following reconstructive head and neck cancer surgery: a prospective double-blind randomized trial. J Oral Maxillofac Surg. 2018;76:2425-32.

135. Dionne RA, Gordon SM, Rowan J, et al. Dexamethasone suppresses peripheral prostanoid levels without analgesia in a clinical model of acute inflammation. J Oral Maxillofac Surg. 2003;61:997-1003.

136. de Sousa Santos JAS, DaSilva LCF, de Santana Santos T, et al. Comparative study of tramadol combined with dexamethasone and diclofenac sodium in third-molar surgery. J Cranio-MaxilloFacial Surg. 2012;40:694-700.

137. Matheny JL. Adrenocorticosteroids: systemic and topical therapy. In: Holroyd SV, Wynn RL, Requa-Clark B, editors. Clinical pharmacology in dental practice. 4th ed. St Louis: Mosby; 1988. p. 238-45.

138. Butler RCD, Vorono AA, Finstuen K. Dosage effects of pulsed steroid therapy on serum cortisol levels in oral and maxillofacial surgery patients. J Oral Maxillofac Surg. 1993;51:750-3.

\section{Additional Reading}

Odontogenic microbiological spectrum.

Lewis MAO, Macfarlane TW, McGown DA. A microbiological and clinical review of acute dentoalveolar abscesses. Br J Oral Maxillofac Surg. 1990;28:359-66.

Poeschl PW, Spusta L, Russmueller G, Seemann R, Hirschl A, Poeschl E, et al. Antibiotic susceptibility and resistance of the odontogenic microbiological spectrum and its clinical impact on severe deep space head and neck infections. Oral Surg Oral Med Oral Pathol Oral Radiol Endod. 2010;110:151-6.

Antibiotic prophylaxis. 
Moreno-Drada JA, Garcia-Perdomo HA. Effectiveness of antimicrobial prophylaxis in preventing the spread of infection as a result of oral procedures: a systematic review and meta-analysis. J Oral Maxillofac Surg. 2016;74:1313-21.

Antibiotics in third molar surgery.

Bezerra TP, Studart-Soares EC, Scaparo HC, Pita-Neto IC, Batista SH, Fonteles CS. Prophylaxis versus placebo treatment for infective and inflammatory complications of surgical third molar removal: a split-mouth, double-blind, controlled, clinical trial with amoxicillin (500 mg). J Oral Maxillofac Surg. 2011;69:e333-9.

Monaco G, Tavernese L, Agostini R, Marchetti C. Evaluation of antibiotic prophylaxis in reducing postoperative infection after mandibular third molar extraction in young patients. J Oral Maxillofac Surg. 2009;67:1467-72.

Lopez-Cedrun JL, Pijoan JI, Fernandez S, Santamaria J, Hernandez G. Efficacy of amoxicillin treatment in preventing postoperative complications in patients undergoing third molar surgery: a prospective, randomized, double-blind controlled study. J Oral Maxillofac Surg. 2011;69:e5-14.

Antibiotics in implants.

Chrcanovic BR, Albrektsson T, Wennerberg A. Prophylactic antibiotic regimen and dental implant failure: a meta-analysis. J Oral Rehabil. 2014;41:941-56.

Antibiotics in orthognathic surgery.

Bentley KC, Head TW, Aiello GA. Antibiotic prophylaxis in orthognathic surgery: a 1-day versus 5-day regimen. J Oral Maxillofac Surg. 1999;57(3):226-30. Discussion 230-2
Tan SK, Lo J, Zwahlen RA. Are postoperative intravenous antibiotics necessary after bimaxillary orthognathic surgery? A prospective, randomized, double-blind, placebo-controlled clinical trial. Int J Oral Maxillofac Surg. 2011;40:1363-8.

Brignardello-Petersen R, Carrasco-Labra A, Araya I, et al. Antibiotic prophylaxis for preventing infectious complications in orthognathic surgery. Cochrane Database of Systematic Reviews. 2015.

Lindeboom JA, Baas EM, Kroon FH. Prophylactic singledose administration of $600 \mathrm{mg}$ clindamycin versus 4-time administration of $600 \mathrm{mg}$ clindamycin in orthognathic surgery: a prospective randomized study in bilateral mandibular sagittal ramus osteotomies. Oral Surgery, Oral Medicine, Oral Pathology and Radiology and Endodontics. 2003;95(2):145-9.

Steroids in third molar surgery.

Graziani F, D'Aiuto F, Arduino PG, et al. Perioperative dexamethasone reduces post-surgical sequelae of wisdom tooth removal. A split-mouth randomized double-masked clinical trial. Int $\mathrm{J}$ Oral Maxillofac Surg. 2006;35:241-6.

Lim D, Ngeow WC. A comparative study on the efficacy of submucosal injection of dexamethasone versus methylprednisolone in reducing postoperative sequelae after third molar surgery. J Oral Maxillofac Surg. 2017;75:2278-86.

Steroids in orthognathic surgery.

Dan AEB, Thygesen TH, Pinbolt EM. Corticosteroid administration in oral and orthognathic surgery: a systematic review of the literature and meta-analysis. J Oral Maxillofac Surg. 2010;68:2207-20.

Open Access This chapter is licensed under the terms of the Creative Commons Attribution 4.0 International License (http://creativecommons. org/licenses/by/4.0/), which permits use, sharing, adaptation, distribution and reproduction in any medium or format, as long as you give appropriate credit to the original author(s) and the source, provide a link to the Creative Commons license and indicate if changes were made.

The images or other third party material in this chapter are included in the chapter's Creative Commons license, unless indicated otherwise in a credit line to the material. If material is not included in the chapter's Creative Commons license and your intended use is not permitted by statutory regulation or exceeds the permitted use, you will need to obtain permission directly from the copyright holder. 